\title{
Magnetic Particles for CTC Enrichment
}

\author{
Peng Liu ${ }^{1,2}$, Pascal Jonkheijm ${ }^{2}$, Leon W. M. M. Terstappen ${ }^{1} \mathbb{D}$ and Michiel Stevens ${ }^{1, *}$ \\ 1 Department of Medical Cell BioPhysics, University of Twente, 7522 NB Enschede, The Netherlnds; \\ p.liu-2@utwente.nl (P.L.); l.w.m.m.terstappen@utwente.nl (L.W.M.M.T.) \\ 2 Department of Molecular Nanofabrication, University of Twente, 7522 NB Enschede, The Netherlands; \\ p.jonkheijm@utwente.nl \\ * Correspondence: m.stevens@utwente.nl; Tel.: +31-53-489-4101
}

Received: 21 October 2020; Accepted: 23 November 2020; Published: 26 November 2020

Simple Summary: For the enrichment of very rare cells, such as Circulating Tumor Cells (CTCs), immunomagnetic enrichment is frequently used. For this purpose, magnetic nanoparticles (MNPs) coated with specific antibodies directed against cancer cells are used. In this review, we look at the properties such a particle needs to have in order to be used successfully, and describe the different methods used in the production of such a particle as well as the methods for their separation. Additionally, an overview is given of the antibodies that could potentially be used for this purpose.

\begin{abstract}
Here, we review the characteristics and synthesis of magnetic nanoparticles (MNPs) and place these in the context of their usage in the immunomagnetic enrichment of Circulating Tumor Cells (CTCs). The importance of the different characteristics is explained, the need for a very specific enrichment is emphasized and different (commercial) magnetic separation techniques are shown. As the specificity of an MNP is in a large part dependent on the antibody coated onto the particle, different strategies in the coupling of specific antibodies as well as an overview of the available antibodies is given.
\end{abstract}

Keywords: CTC; rare cell detection; immunomagnetic separation; magnetic nanoparticle; ferrofluids; non-specific binding; positive enrichment

\section{Introduction}

Magnetic separation has been used as early as 1792 [1], but was for a long time restricted to already magnetic materials. It is therefore not surprising that the first successful use of magnetic separation of blood cells was the separation of inherently paramagnetic red blood cells from different cell populations [2]. Usage of MNPs for cell separation was later demonstrated by Molday et al., who used polymeric microspheres to separate lymphocytes and red blood cells based on surface markers [3]. These first separations on abundant cell populations have initiated the development of multiple MNPs and separation techniques to perfect the magnetic separation of all types of cell populations, including rare cell types, such as Circulating Tumor Cells (CTCs). For the enrichment of CTCs, the most used method is positive enrichment via immunomagnetic separation. The only FDA-cleared system for the enumeration of CTCs is the CellSearch system, which uses MNPs for automatic enrichment of CTCs from a $7.5 \mathrm{~mL}$ blood sample [4].

When using MNPs to separate a specific rare cell population, it is important to consider the characteristics of both the MNPs and the magnetic configuration used. Over the years, many different particles have been proposed for CTC enrichment, and some have been used. Although there have been other reviews on the synthesis of MNPs [5-9], they generally focus on the synthesis process of the bare MNPs, and seldomly further explore their biological applications, especially the specific 
application of rare cell separation. As a consequence, the MNPs discussed are often not suitable for biological applications due to the toxicity of the chemical reagents used in the synthesis method. In this review, we will discuss the ideal characteristics of the MNPs for rare cell separation with a focus on CTCs and describe the existing techniques that can be used to make MNPs suitable for this purpose. Additionally, we will briefly discuss the magnetic configurations used and give an overview of the existing particles.

\section{Immunomagnetic Particles for Rare Cell Enrichment}

CTCs are extremely rare, especially in patients without known metastasis [10,11]. In these patients, the presence of one or more CTC in $7.5 \mathrm{~mL}$ of blood is significantly associated with a higher chance of disease recurrence and death $[10,11]$. With such a low frequency of CTCs, a considerable proportion of patients with one CTC in $7.5 \mathrm{~mL}$ of blood will be missed purely based on the statistical distribution of the CTCs [12]. Although the actual recovery of CTCs in immunomagnetic enrichment cannot be determined in the patient's blood, as the actual number is not known, one can deduct that 30-90\% of the CTCs are recovered from experiments in which tumor cells were spiked into blood [13]. This percentage varies based on the number of target antigens present on the CTC and the characteristics of the MNPs and the magnetic separation configuration. From these facts one can conclude that, to reliably detect the presence of CTCs in such low numbers, the blood volume will have to be significantly increased [14]. To examine the presence of CTCs in larger blood volumes, Diagnostic Leukapheresis (DLA) has been introduced $[15,16]$, through which the mononuclear cell fraction, which also contains the majority of CTCs, can be obtained from the complete blood volume. Through this method, the number of CTCs, which were recovered from a DLA of $5 \mathrm{~L}$ of blood in metastatic patients, was dramatically increased. This increase is needed to be able to perform phenotypic and (epi-)genetic characterization for all patients, as well as secretome analysis, expansion, drug testing and introduction in animal models. Additionally, this increase in sample volume was used to improve the sensitivity of the CTC detection in order to reliably detect CTCs in non-metastatic patients [16]. Whereas, for a metastatic patient where only $1 \mathrm{CTC}$ is found in a $10 \mathrm{~mL}$ blood draw, the number of CTCs found will go up to 500 CTCs upon increasing the volume to $5 \mathrm{~L}$; the number of CTCs that is found in non-metastatic patient is much lower $[10,11]$. Whether the objective is to obtain a sufficient number of CTCs in order to determine the most effective treatment or whether it is to detect their presence in patients with no known metastasis, different requirements need to be met; as for the latter objective, it is important to have a process that allows for a comparison between patients, while for the former objective it is the minimum number of CTCs that is important.

To get a feel for the number of cells that can be expected when processing DLA, we took as an example a blood sample from a metastatic cancer patient with 10 CTCs, a DLA of 5 L of blood from that same patient and a DLA of $5 \mathrm{~L}$ of blood from a non-metastatic patient. For the number of CTCs in the non-metastatic setting, we took as a reference the level of sensitivity needed to detect a tumor at the point when the 5-year risk of metastasis is $1 \%$, which is 9 CTCs/L [17]. The effect of different levels of leukocyte depletion, assuming a CTC enrichment efficiency of $100 \%$, is visualized in Figure 1. In practice, both the efficiency of the CTC collection during a DLA procedure as well as during enrichment will be less than $100 \%$, making the CTC ratio even lower.

The background of white blood cells that remains after the enrichment is an obstacle for many (single cell) analysis techniques. In our experience, a background level of less than 10,000 leukocytes is needed for efficient single cell analysis. If it would be possible to perfect the immunofluorescent labelling of the enriched cell suspension and achieve a perfect detection of CTCs among leukocytes and other objects by fluorescence microscopy or flowcytometry, one could tolerate a higher background level. Fluorescently labelled antibodies can, however, non-specifically bind to non-target antigens through, for example, their Fc-receptors, and a background of $0.1-0.01 \%$ is quite common [18]. This non-specific binding increases when intracellular antigens are targeted as the fluorescently labelled antibodies are more prone to stick to the intracellular components. The use of multicolor antibody 
panels can significantly decrease impact of this background as usually the background affects all colors. Besides using at least one positive identifier of the target cell, one negative identifier already increases the specificity of the detection as well. The ability to detect a CTC among other cells, after immunofluorescent staining, depends also strongly on the number of antigens present on the target cells of the CTCs. This numbers of antigens can strongly vary and is a variable that cannot be controlled. A general rule for rare cell detection is therefore to use the fluorochrome with the highest intensity and smallest coefficient of variation after staining, as well as the lowest non-specific binding, to identify the target cells.

\begin{tabular}{|c|c|c|c|c|c|c|c|}
\hline & \# of WBC & $\#$ of CTC & Starting ratio & CellSearch (3.3) & 4 log depletion & 5 log depletion & 6 log depletion \\
\hline A) Blood & $5^{\star} 10^{\wedge} 7 \mathrm{WBC}$ & $10 \mathrm{CTC}$ & $0.000020 \%$ & $0.040 \%$ & $0.20 \%$ & $1.96 \%$ & $16.7 \%$ \\
\hline $\begin{array}{c}\text { Metastatic } \\
\text { disease }\end{array}$ & - & • & & & & & \\
\hline B) $D L A$ & $1^{\star} 10^{\wedge} 10 \mathrm{WBC}$ & 5000 CTC & $0.000025 \%$ & $0.050 \%$ & $0.25 \%$ & $2.44 \%$ & $20.0 \%$ \\
\hline $\begin{array}{c}\text { Metastatic } \\
\text { disease }\end{array}$ & & & & & & & \\
\hline C) DLA & $1^{\star} 10^{\wedge} 10 \mathrm{WBC}$ & $45 \mathrm{cTC}$ & $0.00000006 \%$ & $0.000125 \%$ & $0.0006 \%$ & $0.006 \%$ & $0.062 \%$ \\
\hline $\begin{array}{l}\text { Non- } \\
\text { Metastatic } \\
\text { disease }\end{array}$ & & - & & & & & \\
\hline
\end{tabular}

Figure 1. Theoretical comparison of the sample size, number of Circulating Tumor Cells (CTCs) and CTC and White Blood Cell (WBC) ratios in the starting material and enriched samples with increasing levels of WBC depletion. (A) $10 \mathrm{~mL}$ blood of a metastatic cancer patient containing $10 \mathrm{CTCs}$; (B) $100 \mathrm{~mL}$ DLA with $10^{10}$ mononuclear cells of the same metastatic cancer patient containing 5000 CTCs; (C) $100 \mathrm{~mL}$ DLA with $10^{10}$ mononuclear cells from a non-metastatic cancer patient with $45 \mathrm{CTCs}$ that can lead to overt metastasis.

\section{The Characteristics of an Ideal Magnetic Particle for Cell Separation}

Ideally, MNPs and the system for their separation allow for fast, selective separation of one or more subpopulations of cells. The first requirement of such a particle and the used separation setup is that the force exerted onto the cell through the bound MNPs is sufficient for it to be separated from the non-target cells. In order to assess the magnitude of this force in relation to the other forces at play, Chen et al. conducted a force analysis on the target tumor cells combined with MNPs [19]. Under the external magnetic field, the movement of target cells in the flow environment is affected by the magnetic force $\left(F_{\mathrm{mag}}\right)$, the hydrodynamic drag force $\left(F_{\mathrm{drag}}\right)$ and the net gravitational force after accounting for buoyancy. As the magnetic force (about $10^{-10} \mathrm{~N}$ ) received by the cell is estimated to be much larger than the net gravitational force (about $10^{-12} \mathrm{~N}$ ), only $F_{\text {mag }}$ and $F_{\text {drag }}$ are considered to simplify the calculation [20]. A scematical overview of the forces during a magnetic separation can be found in Figure 2. 


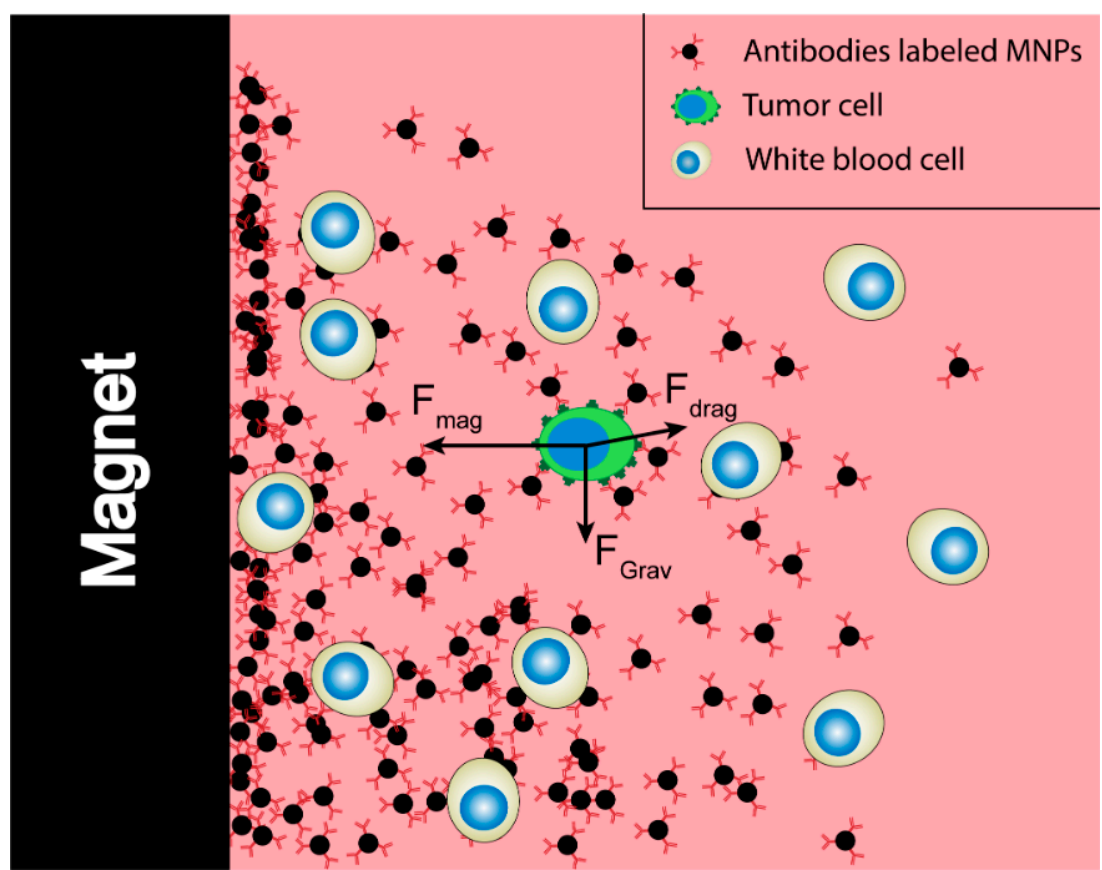

Figure 2. Virtual force analysis of the target cells during immunomagnetic separation.

The force exerted by a single magnetic particle $\left(F_{p}\right)$ is the result of the magnetic moment $(|\mathrm{M}|)$ of the particle and the gradient of the magnetic flux density, $\nabla B$, as seen in Equation (1):

$$
F_{p}=|M| \nabla B
$$

This magnetic moment of the magnetic nanoparticle is given by Equation (2):

$$
|M|=\frac{V_{p} \Delta \chi_{p}}{\mu_{0}} B
$$

Here, $\mu_{0}$ is the magnetic susceptibility of a vacuum, a constant, making the magnetic moment of a single magnetic particle dependent on

- $\quad$ the volume of a single magnetic nanoparticle $\left(V_{p}\right)$;

- the magnetic susceptibility of the magnetic nanoparticle $\left(\Delta \chi_{p}\right)$;

- the magnetic field generated by the external magnetic flux source $(B)$.

As the cells are pulled through the surrounding liquid toward the magnet, they will experience a drag force. Assuming a laminar nature of the flow, and therefore a low Reynolds number, this force can be estimated using Stokes' law. Here, the drag force is given as a function of the viscosity $\eta$, particle radius $r$ and velocity $v$, as seen in Equation (3).

$$
F_{d}=6 \pi \eta r v
$$

The magnetic force on a cell is the sum of the forces of all the MNPs bound to the cell. As these forces will balance out, we can determine the resulting velocity using Equation (4), where $\mathrm{N}$ indicates the number of particles bound to the cell.

$$
v=\frac{N V_{p} \Delta \chi_{p}}{12 \pi \eta r \mu_{0}} \nabla B^{2}
$$


Based on this equation, as many MNPs as possible should attach onto the cell surface $(N)$, and a magnetic configuration with a sufficiently large magnetic field $(B)$ and the highest possible magnetic field gradient $(\nabla B)$ needs to be used to separate the cells; the ideal magnetic nanoparticle should thus have a high magnetic susceptibility $\left(\Delta \chi_{p}\right)$ and a large volume $\left(V_{p}\right)$. Not considered in these equations is the ability of MNPs to bind to their target. With an increase of particle size, the particles will at some point become non-colloidal, causing them to sink to the bottom quickly, without having a chance to attach to the target. The limit at which a particle is no longer colloidal can range from around $10 \mathrm{~nm}$ to several micron [21]. This large range is due to its dependence not only on particle size and density, but also on the particles shape and surface chemistry, as these together with the suspending solution determine the particles surface charge [22]. This non-colloidal nature in combination with a decrease in stochastic movements [23] and the steric hinderance that effects larger particles will cause a decrease in binding efficiency. One avenue used to increase the possible collisions between target cells and nanoparticles is to expose the sample to changing magnetic gradients. In the CellTracks Autoprep, this is, for example, achieved by "magnetic incubation", which involves moving the magnets to and from the sample tube multiple times during sample incubation as well as rotation of the sample tube [4].

Although, for an optimal capture, it would seem best to use particles for which very few or even a single bound particle will cause the target cell to be captured; the statistical probability of it being captured due to a non-specific interaction will increase when the number of non-specific interactions needed for capture decreases.

\section{Superparamagnetic and Magnetic Susceptibility}

The highest magnetic susceptibility is achieved by using ferromagnetic materials, in particular $\mathrm{Fe}_{3} \mathrm{O}_{4}$, also known as magnetite. The downside of this type of particle is that it remains magnetic when the external field is removed, resulting in nanoparticle clumping. This can be prevented by using paramagnetic materials, but these have a much lower susceptibility.

The solution lies in superparamagnetic nanoparticles, which are ferromagnetic particles small enough to consist of a single magnetic domain. When an external magnetic field is applied, the magnetic domain inside the nanoparticles will be aligned instantly and have the same magnetic direction as the external magnetic field (Figure 3A). When the magnetic field is removed, this magnetic alignment remains, causing the particle to stay magnetic. How much alignment is retained is determined by the retentivity of the material. The strength of an opposing magnetic field needed to reduce this field to 0 is called the coercivity and is used as a measure of how magnetic a material has become. If, however, the size of a particle is below the critical value $(\sim 15-20 \mathrm{~nm})$, the thermal energy will cause spontaneous magnetization reversal, resulting in the particles being randomly aligned with 0 coercivity (Figure 3B) [24]. In Figure 3C, it can be seen that by using superparamagnetic particles there is no remaining magnetization after removal of the magnetic field. In this way the agglomeration of nanoparticles in the absence of an external magnetic field can be avoided. 
A)

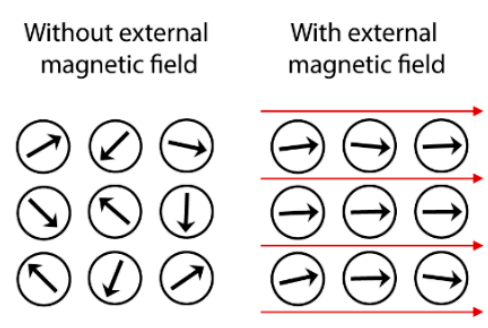

B)

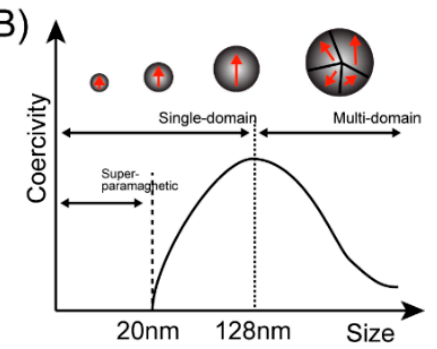

C)

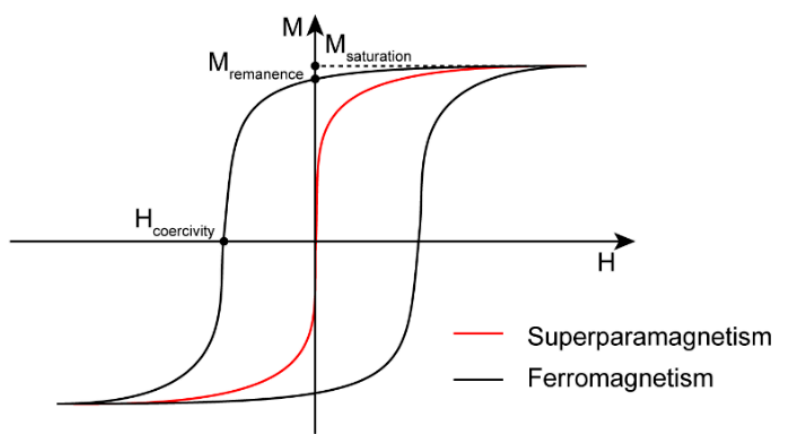

Figure 3. Overview of different properties of ferromagnetic and superparamagnetic materials (A) Schematic diagram of single magnetic domain direction with or without an external magnetic field. (B) The relationship between coercivity and size of $\mathrm{Fe}_{3} \mathrm{O}_{4}$; Reprinted with permission from [24]. (C) Hysteresis characteristic of the ferromagnetic and superparamagnetic nanoparticles (NPs).

It is generally believed that the critical size of superparamagnetic nanoparticles is below $20 \mathrm{~nm}[24,25]$. This means that their magnetic properties are also affected by the spin canting effect. This effect is caused by a lack of complete alignment in the spins of the surface atoms and leads to a lower magnetization of small-sized MNPs [26].

Iron oxide nanoparticles can be considered as composed of a magnetic core and a magnetically disordered shell. The thickness of this spin-canted surface layer of the nanoparticles is $0.5-0.9 \mathrm{~nm}$ for all particle sizes [26]. This means that the relative portion of the spin-canted layer increases for smaller particles while the portion of the magnetic core and thereby the magnetization of the particles increases for larger sizes (see also Figure 4). This results in the ideal magnetic particle size being just below the superparamagnetic limit.

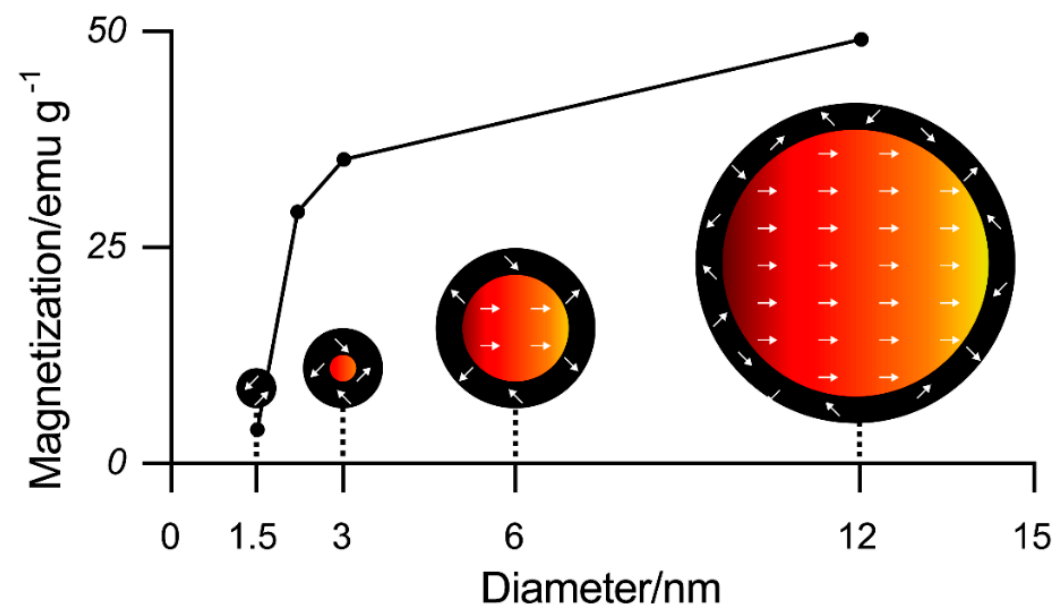

Figure 4. Magnetization value of the iron oxide nanoparticles with different sizes at $300 \mathrm{~K}$ and a visual description of the spin canting effect in various sizes of iron oxide nanoparticles (tilted layer $=0.9 \mathrm{~nm}$ ). Red represents the magnetic cores and black the disordered shells. Reprinted with permission from [26]. 
Daou et al. [27] studied two different coatings and reported that inorganic-organic interactions on the surface of nanoparticles can also affect the magnetic properties of nanoparticles. For example, the carboxylate coupling agent causes spin canting in the oxide layer, thereby reducing the saturation magnetization, but the phosphonate molecule does not.

As a superparamagnetic particle is at maximum around $20 \mathrm{~nm}$, the particle volume is extremely limited and single superparamagnetic nanoparticles are not quickly attracted by magnets. This size limitation of the superparamagnetic particles can be circumvented by the agglomeration of many superparamagnetic nanoparticles together in a matrix of non-magnetic material in order to get both the wanted superparamagnetic behavior as well as an increased volume. Various methods have been used to prepare large-parameter superparamagnetic particles for biological separation, and the current commonly used sizes are from $50 \mathrm{~nm}$ to $4.5 \mu \mathrm{m}$.

Whereas in Equation (4) the number of MNPs was depicted as a single factor, McCloskey et al. proposed a formula to express the magnetophoretic mobility of immunomagnetically-labeled cells to reflect the number of particles bound. They split this number of bound particles up into three contributing factors, as can be seen in Figure 5 [28].

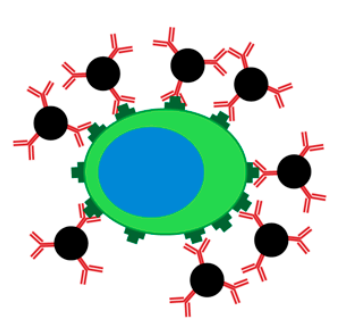

Bind to more antigens

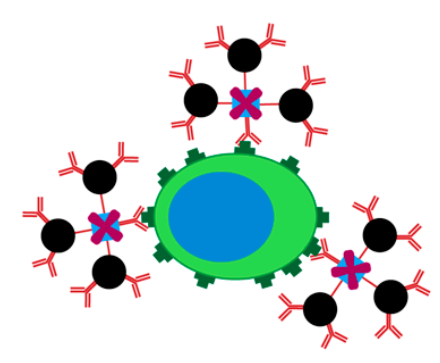

More particles per antigen

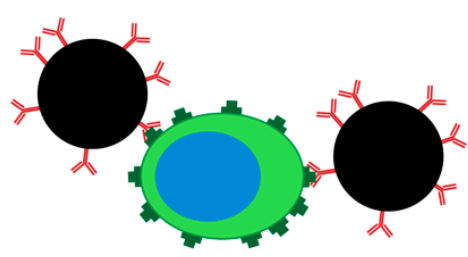

Increase particle size

Figure 5. Schematic representation of the three ways to increase the amount of magnetic material coupled to a target cell.

The elaboration of Equation (4) in this way leads to the velocity of a labeled cell being expressed by

$$
v=\frac{A B C \psi N_{a} V_{p} \Delta \chi_{p}}{12 \pi \eta r \mu_{0}} \nabla B^{2}
$$

Here, $A B C$ is the antibody binding capacity of a cell population, $\psi$ is the secondary antibody binding amplification factor and $N_{a}$ is the number of MNPs bound to a single antibody.

These factors can increase the volume of magnetic material attached to the cell and thereby its magnetic moment. The force exerted on the cell is then determined by Equation (1), in which this magnetic moment all particles attached to the cells is multiplied by the magnetic field gradient. For this reason, the highest magnetic force is achieved when the magnetic field is sufficiently strong to reach the saturation magnetization of the particle used while creating the highest possible magnetic field gradient throughout the sample volume. Figure 6 shows the COMSOL 5.4 modelling of $10 \mathrm{~mm}$ by $10 \mathrm{~mm}$ N52 magnets in different yoked configurations with their magnetic flux density and flux density gradient. 


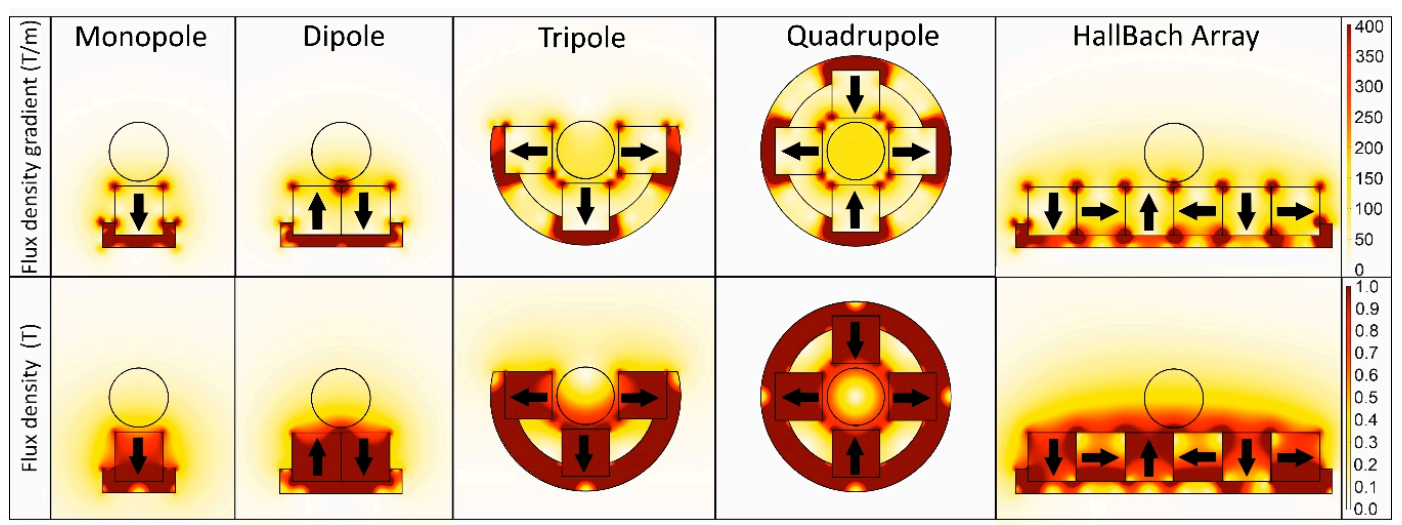

Figure 6. Magnetic flux and flux density for the same size magnets in different magnetic configurations. The position of a circular tube containing the sample is shown in each configuration.

Which configuration is best depends on the magnetic particle as well as on the size and shape of the container used. The dipole configuration is often used as it is simple and the cells and particles are collected at a single point. This configuration can be extended form an array of dipoles, essentially a row of magnets with alternating orientations. When using small magnets in this way, a high magnetic force can be achieved over a short distance. For cylindrical tubes, a quadrupole is often the most fitting configuration, and therefore it also was used for sample preparation in the original CellSearch system [29]. However, in order to be able to move the magnets away from the tube without the need for lateral movement, a tri-pole is used during the first steps in the commercialized CellSearch system [4]. In later steps, a dipole is used as it causes the collection of MNPs and cells at a single position in the tube, facilitating efficient resuspension without the need to vortex [4]. The Halbach array is more complex to assemble but has the benefit of the magnetic field reaching further away from the magnet compared to an array of dipoles.

Using larger magnets will increase the reach of the magnetic field, but at a loss of the magnetic gradient. By using very small magnetic elements, the magnetic gradient can be increased, resulting in a large force over a short distance. Osman et al., for instance, used micromagnets, resulting in a high gradient close to the magnets, but therefore needed the cells to be very close to the surface to allow capture [30]. Another way to create a high local field gradient is to introduce very small parts of ferro or (super-)paramagnetic material in close proximity to the cells. The material will be magnetized by the external magnetic field and become magnetic, creating very high magnetic gradients over a short distance, allowing the separation of cells in close proximity. This type of magnetic field gradient enhancement is employed, for instance, in Miltenyi separation columns as well as several microfluidic magnetic separation chips [31-33].

As can be seen in Equation (2), the magnetic field is also of influence on the magnetic moment of the particles. As depicted in Figure 3C, this relation between the applied magnetic field and the resulting magnetization and, therefore, the magnetic moment of the superparamagnetic particles, is not a linear relation but is limited by the saturation magnetization. When the saturation magnetization of the particles is reached, a further increase in the magnetic field will not increase the magnetic force. In this regard, it is important to realize that when the magnetic properties of particles are discussed, the saturation magnetization is often used as a parameter to express magnetic force, while perhaps with the configuration used, especially in the region furthest from the magnets, the field might be insufficient to reach this level of magnetization. The saturation magnetization is dependent on the synthesis method used to create the particles.

\section{Synthesis Methods of MNPs}

The synthesis of MNPs can be done via either physical or chemical methods. Physical methods usually require harsh reaction conditions, and the shape and particle size are difficult to control. 
Gas phase deposition and electron beam lithography are commonly used examples of physical methods. Chemical methods include co-precipitation, solvothermal reactions (hydrothermal reactions), thermal decomposition (hydrolysis and thermolysis of precursors), microemulsions, sol-gel synthesis and sono-chemical synthesis. For magnetic cell separation, almost exclusively particles synthesized via chemical methods have been used. Table 1 lists four synthesis methods to produce MNPs, including some of their characteristics. It also shows examples of TEM images of MNPs of different sizes and made through different processes. The merits and drawbacks of the four methods are described below.

Table 1. Different synthetic methods and the characteristics of the products obtained.

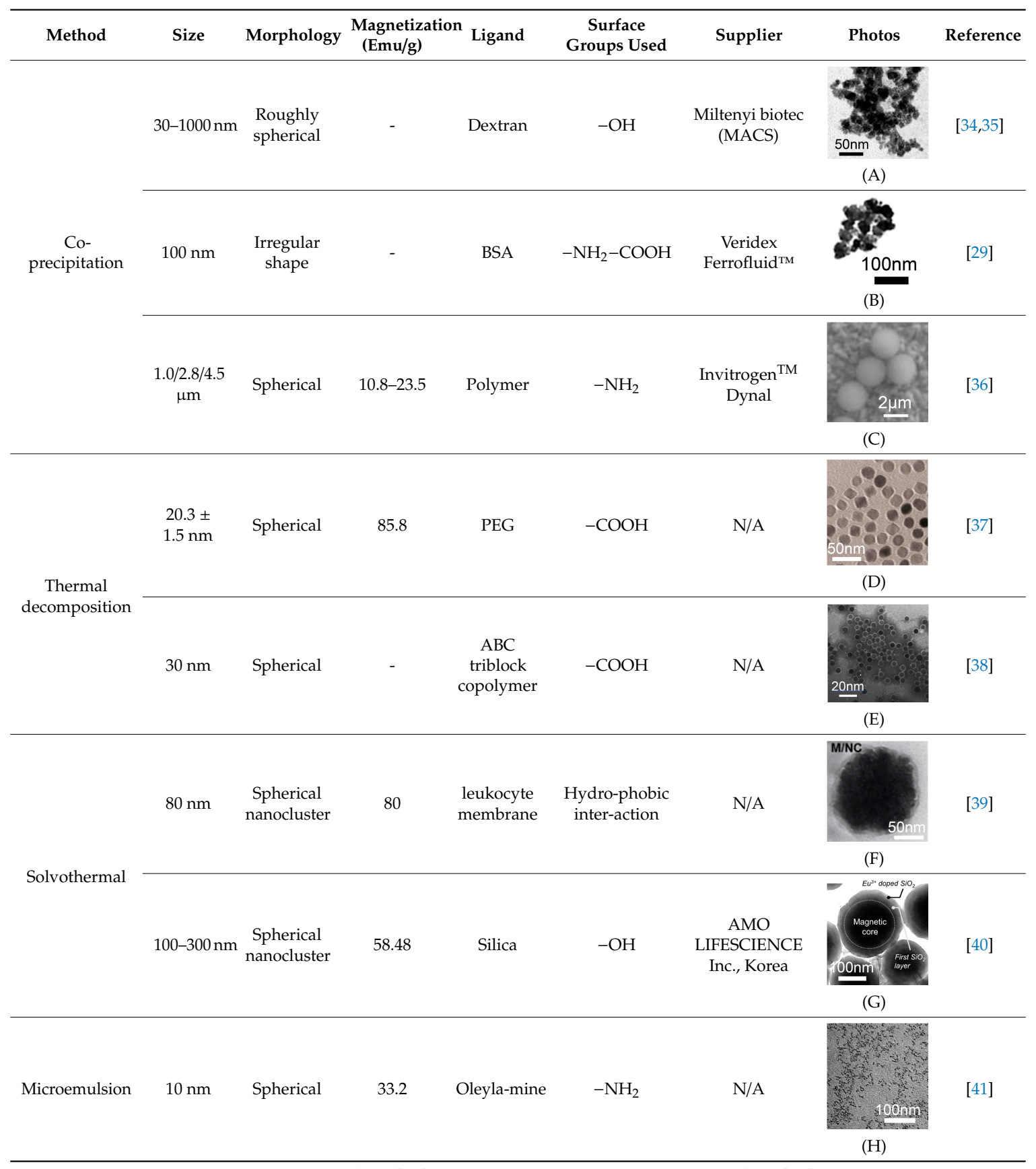

Picture (C) reprinted with permission from [36]; Picture (D) reprinted with permission from [37]; Picture (E) reprinted with permission from [38]; Picture (F) reprinted with permission from [39]; Picture (G) reprinted with permission from [40]; Picture $(\mathrm{H})$ reprinted with permission from [41]. 


\subsection{Co-Precipitation}

Co-precipitation is one of the most commonly used methods for preparing superparamagnetic iron oxide nanoparticles, which can be traced back to 1852 [42]. Almost all initial MNPs were created by co-precipitation. For the first cell separation, as was reported by Molday in 1977, polystyrene beads were used, but in 1982 Molday et al. first synthesized iron oxide particles coated with dextran by co-precipitation with ferric chloride, ferrous chloride and dextran [43]. Almost all MNPs developed in the following decades were created by co-precipitation. The diameter of these roughly spherical iron-dextran particles was 30-40 nm, including a 10-20 $\mathrm{nm} \mathrm{Fe}_{3} \mathrm{O}_{4}$ core [43]. These ferrofluids are the precursor of the commercially available MACS ${ }^{\circledR}$ MicroBeads made by Milteyni Biotec, which have a size of $50 \mathrm{~nm}$.

The reaction process is to add alkali to an aqueous solution of a certain proportion of ferrous salt and ferric salt. Then, the reaction shown in Equation (6) occurs to obtain iron oxide nanoparticles.

$$
\mathrm{Fe}^{2+}+2 \mathrm{Fe}^{3+}+8 \mathrm{OH}^{-} \rightarrow \mathrm{Fe}_{3} \mathrm{O}_{4}+4 \mathrm{H}_{2} \mathrm{O}
$$

The co-precipitation method has the advantages of being a low-cost, simple process that can be used on a large scale. However, the bare $\mathrm{Fe}_{3} \mathrm{O}_{4}$ nanoparticles agglomerate easily due to their extremely high surface energy and will bind non-specifically with biological components. In order to prevent this issue, a ligand, such as dextran, BSA or PEG, is commonly added during preparation. Alternatively, the surface of the particles is coated after preparation.

Ugelstad et al. first synthesized polystyrene particles of uniform size in 1976 [44]. The size could be adjusted between 0.5 and $20 \mu \mathrm{m}$, and then the particles were magnetized by the incorporation of particles made using the co-precipitation method. This process was patented in 1988; this is the basis of the commercially available Dynabeads.

By mixing soluble iron salts of $\mathrm{Fe}^{3+}$ and $\mathrm{Fe}^{2+}$ in a ratio of 1:2 together with latex, iron ions enter the polymer particles. The polymer particles contain functional groups, such as amino groups, to fix the iron ions. The last step is to raise the $\mathrm{pH}$ to form hydroxides, causing the $\mathrm{Fe}_{3} \mathrm{O}_{4} \mathrm{MNPs}$ to precipitate the iron ions and become fixated inside. The obtained MNPs contain a uniform concentration of magnetic iron oxide, which is generally above $5 \%$.

Owen and Liberti et al. first mixed the iron salt directly with a BSA solution, and then raised the $\mathrm{pH}$ value to generate $\mathrm{Fe}_{3} \mathrm{O}_{4}$ by co-precipitation in situ to prepare the magnetic particles [45]; later, the method was improved, and BSA was used to coat the already prepared $\mathrm{Fe}_{3} \mathrm{O}_{4}$ nanoparticles to obtain a type of MNP they called "ferrofluids". The BSA coating reduces the non-specific binding and is rich in functional groups that can be used to bind streptavidin or antibodies. This process was patented and became the core technology for the fabrication of the MNPs used in the CellSearch system.

Feng et al. used PAA as a ligand and made hydrophilic magnetic nanoparticles through the co-precipitation method to enhance the potential encoding capacity of their beads called MRBLEs [46].

Although it serves as the basis of many commercial MNPs, the co-precipitation method also has some shortcomings. For example, the crystallinity of the product obtained by this method is low, which will affect its magnetic strength.

\subsection{Thermal Decomposition}

This method generally uses iron salt as a precursor, oleic acid as a ligand and octadecene as a solvent to prepare superparamagnetic iron oxide nanoparticles at a high temperature (e.g., $320^{\circ} \mathrm{C}$ ) [47]. The product obtained by the thermal decomposition method has the advantages of a controllable and narrowly distributed particle size and high magnetization, but at the same time, because the long-chain hydrocarbons used to control the shape and size also form the hydrophobic surface of the nanoparticles, surface modification is required to make them hydrophilic and biocompatible; therefore, some researchers have also tried to directly synthesize hydrophilic nanoparticles. [48]. 
$\mathrm{Xu}$ et al. [38] used this method to prepare oil-soluble nanoparticles of about $30 \mathrm{~nm}$, and then coated them with amphiphilic polymers containing carboxyl groups to obtain nanoparticles with good biocompatibility and reactive carboxyl groups on the surface. The HER-2 antibody was then conjugated to the surface of the particle through covalent linkage of the amino and carboxyl groups.

Unni et al. [37] synthesized ferric oleate from acetylacetone and oleic acid, and then mixed it with octadecene and injected it into dodecane at a stable rate to obtain iron oxide nanoparticles with a diameter of $20.3 \pm 1.5 \mathrm{~nm}$. The surface was coated with streptavidin functionalized PEG to reduce the non-specific binding and allow the biotinylated anti-EpCAM (Epithelial Cell Adhesion Molecule) antibody to be bound to the surface of the nanoparticle.

Alternatively, Ge et al. [49] used PEG- $(\mathrm{COOH})_{2}$ as a ligand to synthesize the hydrophilic magnetic nanoparticles in a one-step process through thermal decomposition. Here, the size of the MNPs can be adjusted between 4.2 and $17.5 \mathrm{~nm}$ by changing the length of the PEG and the ratio of the reactants.

\subsection{Solvothermal}

The solvothermal method is very similar to the hydrothermal method but uses a non-aqueous solvent. The method is carried out by sealing a reaction mixture in a Teflon-lined autoclave and then placing it at a temperature higher than the normal boiling point of the solvent. The solvent is then in a critical state, which greatly promotes the dissolution of the material. The method is easy to operate and can be prepared on a large scale. At present, researchers can already use this method to control the product morphology and particle size.

For example, Kim et al. [40] used this method to synthesize hydrophilic superparamagnetic nanoclusters with an adjustable particle size in the range of 100-300 $\mathrm{nm}$ in one step. The nanoclusters consisted of 11-13 nm nanocrystals. Then, by encapsulating the silica shell, a core-shell structure was obtained, which further improved its biocompatibility, and to which antibodies were attached to capture cells.

Zhang et al. [39] used ferrous sulfate as a precursor and PEI as a surfactant to synthesize iron oxide nanoclusters in a mixture of ethylene glycol (EG) and diethylene glycol (DEG) using a one-step solvothermal method. Then, the surface was modified with a leukocyte membrane to reduce the non-specific binding of the nanoparticles, and the aptamer SYL3C, specific for EpCAM-positive tumor cells, was bound on the surface.

\subsection{Microemulsion}

Microemulsion is a method to synthesize particles with a controlled shape and size. A binary system of microemulsion (water/surfactant or oil/surfactant) can be formed by different types of self-assembled structures (such as spherical and cylindrical micelles), so that the desired particle growth, nucleation and coalescence can be achieved [5].

Vidal-Vidal et al. [41] used the microemulsion method to encapsulate nanoparticles during their formation by co-precipitation in order to synthesize MNPs. The application of these particles in a biological application, however, requires extensive washing and stabilization treatments due to the remaining surfactants.

\section{Methods to Bind Targeting Ligands on Magnetic Particles}

In order to bind a magnetic particle to a specific cell type the surface of the particle can be coated with ligands that specifically bind to antigens present on the surface of the targeted cell type. Most frequently, antibodies recognizing the cell's species-specific antigens are used for this purpose. The antibody-antigen immunological binding has a high specificity, which is needed to capture rare cells in the blood. The specificity and sensitivity of the immunoactive magnetic particle can be separated into the characteristics of the antibodies used and the characteristics of the magnetic particle. For the latter, the non-specific binding of the base particle can be influenced by the ligand-binding 
method, while for the antibody its affinity for its target and the density of expression on the target and non-target cells is of importance.

\subsection{Antibodies and Ligands Used for CTC Enrichment}

Antigens that are solely expressed on cancer cells have not been reported. One antigen that comes closest to this is the VAR2CSA malaria protein [50], which is not present on non-cancerous cells of hematopoietic origin and expressed on the cell surface of cancer cells but not their normal counterpart. An exception is the presence of the trophoblast on non-cancerous cells in the placenta. To identify CTCs in blood, one generally relies on antibodies that do not recognize antigens expressed on cells of hematopoietic origin or which are expressed at levels that are orders of magnitude lower as compared to the target cancer cells. In most cases monoclonal antibodies are used, as they are more specific as compared to polyclonal antibodies. As such, the monoclonal antibodies have less non-specific binding; additionally, they can be produced in a reliable and reproducible manner. Another option to capture a specific cell type consistently are aptamers. These chemically synthesized molecules are smaller in size and can be conjugated to nucleotides or functional groups. Aptamers have been increasingly used as targeting ligands for CTCs for detection. Due to the low cost and better stability of aptamers, they can be applied under a wide range of conditions [51].

The most commonly used antibody for CTC enrichment is the anti-EpCAM antibody. The EpCAM antigen is expressed on cells of epithelial origin and as such on most carcinomas [52,53]. As EpCAM is not expressed on blood cells, it can be used to capture CTCs from many different types of cancer, including lung, prostate, colon, breast and bladder cancer [29]. The most used system for the immunomagnetic enrichment of CTCs is the CellSearch system, which uses anti-EpCAM antibody-labeled ferrofluids to capture CTCs, and it has been shown that the EpCAM-positive CTC load is strongly correlated with a poor prognosis [54-56]. However, relying on EpCAM also has some limitations, such as its different expression levels between different subtypes of tumor cells; also, its expression level being downregulated during the epithelial-mesenchymal transformation (EMT) process may cause false negative results [52]. Due to the EMT, some tumor cells can change from a high to a low EpCAM expression and can no longer be captured using anti-EpCAM targeting ligands [57]. As EMT may promote the spread of tumor cells in the body, also these cells are of great interest to capture. Other antigens targeted to capture CTCs from the peripheral blood include Her-2 [58,59], EGFR [59-62], CD146 [13,63,64] and MUC-1 [65-68]. Additionally, the malaria rVAR2 protein and oncofetal chondroitin sulfate have been introduced as markers for CTC enrichment [69-73].

In Table 2, a list of antigens recognized by antibodies that are generally not expressed by blood cells is provided. The table is sorted by the presence of the antigens on epithelial cells followed by endothelial cells, neural cells and mesenchymal cells. Their expression on normal tissue and the various types of cancer can be found in the protein atlas (https://www.proteinatlas.org/search/). For the antigens where the (attempted) use for CTC capture is known, references are included. From the table, the large differences in expression on the cells of origin becomes clear. Each antigen may have different epitopes recognized by antibodies that do not cross react and their affinity for the target can be quite different, leading to differences in specificity and sensitivity for target antigen detection. For CTC enrichment, the importance of testing multiple antibodies directed against EpCAM and the possibility of an increase of capture by combining multiple low-affinity antibodies has been shown [74]. Detection efficiency for a single antigen could be increased by using different antibodies against the same antigen. Antigens expressed intracellularly, such as the cytokeratins, are more difficult to use for immunomagnetic enrichment, but not impossible, as shown by the use of small Milteny ferrofluids targeting intracellular cytokeratins [75]. Presence of the target solely in the nucleus makes this challenge even greater. 
Table 2. Overview of the antigens (used) for immunomagnetic tumor cell enrichment.

\begin{tabular}{|c|c|c|c|c|}
\hline $\mathrm{CD} \# / \mathrm{Abbr}$. & Name & Expression & Location & $\begin{array}{l}\text { Used for } \\
\text { CTC Capture }\end{array}$ \\
\hline \multicolumn{5}{|c|}{ Epithelial cells and no or few hematopoietic cells } \\
\hline CD44 & & ep & $\mathrm{Cs}, \mathrm{ic}$ & Yes [76] \\
\hline CD49f & Integrin Alpha 6 & ep & CS & Yes [76] \\
\hline CD66e & CEA (CAM5) & ep (colon) & cs & No \\
\hline CD66f & PSG1 & ep, pl, li & Cs & No \\
\hline CD104 & Integrin beta4 & ep, ed, ne, ke & CS & No \\
\hline CD118 & LIFR & ep & CS & No \\
\hline CD133 & Prominin-1 & ep, hs, ed, ne & Cs & No \\
\hline CD164 (1) & MUC-24 & ep (prostate cancer, bone mets) & CS & No \\
\hline CD164 (2) & & ep (bowl, lung, thyroid) & cs & No \\
\hline CD164 (3) & & hs, sc (bone marrow) & Cs & No \\
\hline CD175 & Tn & $\mathrm{ep}, \mathrm{sc}$ & Cs & No \\
\hline CD175s & Sialyl Tn & ep, ed, erythroblasts, & Cs & Yes [77] \\
\hline CD176 & $\begin{array}{c}\text { Thomsen-Friedenreich } \\
\text { antigen }\end{array}$ & $\mathrm{ep}, \mathrm{sc}$ & Cs & No \\
\hline CD227 & MUC-1 & ep, sc & cs & Yes [65-68] \\
\hline CD283 & TLR3. & ep, fi, ne, dc & $\mathrm{cs}$, ic & No \\
\hline CDw293 & BMPR-1B & $\mathrm{ep}, \mathrm{ms}, \mathrm{bc}$ & CS & No \\
\hline CD318 & CDCP1 & ep, hs & $\mathrm{CS}$ & No \\
\hline CD325 & N-Cadherin & ep, ne, mu (cardiac), fi, pa, li & cs, ic & Yes [78-80] \\
\hline CD326 & EpCAM & ep, sc (embryonic) & CS & Yes $[29,54,55]$ \\
\hline CD331 & FGR1 & ep, ed, fi, ms, mu (cardio), ne & Cs & No \\
\hline CD331-4 & FGFR1-4 & ne, ki, te & & No \\
\hline CD332 & FGFR2 & ep, li, fi, ne, & $\mathrm{Cs}, \mathrm{ic}$ & No \\
\hline CD340 & erbB-2 kinase/ Her-2 & ep (breast), ed, ke, hs, sc & cs, ic & Yes $[58,59]$ \\
\hline CD344 & Frizzled- 4 & ep, ms, ne, ki, te & CS & No \\
\hline CD338 & ABCG2 & ep, li, ki, lu, pl & CS & No \\
\hline CD350 & Frizzled-10 & ep (colon), ki, lu, br, pl & Cs & No \\
\hline CK & Cytokeratins 1-23 & ep & ic & Yes [75] \\
\hline AR & Androgen receptor & ep & ic, in & No \\
\hline EGFR & $\begin{array}{l}\text { Epithelial Growth } \\
\text { Factor/Her-1 }\end{array}$ & ep, pl, pa, ki, li & cs & Yes [59-62] \\
\hline ER & Estrogen receptor & ep & ic, in & No \\
\hline PSMA & $\begin{array}{l}\text { Prostate-Specific } \\
\text { Membrane Antigen }\end{array}$ & ep (prostate) & cs, ic & Yes [81-83] \\
\hline Trop2 & $\begin{array}{l}\text { Tumor-associated Ca } \\
\text { signal transducer } 2\end{array}$ & ep & cs & Yes [76] \\
\hline
\end{tabular}


Table 2. Cont.

\begin{tabular}{|c|c|c|c|c|}
\hline \multicolumn{5}{|c|}{ Endothelial cells and no or few hematopoietic cells } \\
\hline CD62E & E-selectin & ed (activated) & CS & Yes [84-87] \\
\hline CD144 & VE Cadherin & ed, sc & CS & No \\
\hline CD146 & MCAM & $\begin{array}{l}\text { ed, sm, me, dc, T-cells } \\
\text { (activated) }\end{array}$ & Cs & Yes $[13,63]$ \\
\hline CD201 & EPCR & ed & Cs & No \\
\hline CD202b & TIE2 & ed, angioblasts & CS & No \\
\hline CD228 & Melanotransferrin & ed, sc, me & Cs & No \\
\hline CD248 & Endosialin & ed (tumor), fi & CS & No \\
\hline CD266 & TWEAK R & ed & CS & No \\
\hline CD299 & $\begin{array}{l}\text { C-type lectin domain } \\
\text { family } 4 \text { member } \mathrm{M}\end{array}$ & ed, li, lymph node & CS & No \\
\hline CD300g & CLM-9 & ed & $\mathrm{cs}, \mathrm{ic}$ & No \\
\hline CD309 & VEGFR-2 & ed, sc & CS & No \\
\hline CD322 & JAM-B & ed (high) & CS & No \\
\hline CD362 & Syndecan-2, & ed, sm (vascular), fi, me & cs & No \\
\hline \multicolumn{5}{|c|}{ Neural cells and no or few hematopoietic cells } \\
\hline CD246 & ALK & ne (embryonic CNS \& PNS & $\mathrm{cs}, \mathrm{ic}$, in & No \\
\hline CD271 & NGF receptor & ne, ms (bone marrow) & cs & No \\
\hline \multicolumn{5}{|c|}{ Mesenchymal cells \& no or few hematopoietic cells } \\
\hline CD90 & Thy-1 & $\mathrm{fi}$ & CS & No \\
\hline $\mathrm{CD} 167 \mathrm{~b}$ & DDR2 & bc, he, lu & $\mathrm{cs}$, ic & No \\
\hline CD292 & BMPR-1A & $\mathrm{mu}$ (skeletal), bc, ms & CS & No \\
\hline CD331-4 & FGFR1-4 & ne, ki, te & cs & No \\
\hline CD339 & Jagged1, & $\begin{array}{l}\text { st (bone marrow), ep (thymic), } \\
\text { ed, ne, ke, ov, pr, pa, pl, he }\end{array}$ & cs & No \\
\hline CD333 & FGFR & ne, ki, te & CS & No \\
\hline c-Met/HGF & $\begin{array}{l}\text { Hepatocyte growth } \\
\text { factor }\end{array}$ & $\mathrm{pl}$ & cs & No \\
\hline Vimentin & Vimentin & $\mathrm{ms}$ & ic & No \\
\hline FAP & $\begin{array}{l}\text { Fibroblast activation } \\
\text { protein, Seprase }\end{array}$ & $\mathrm{ep}, \mathrm{ms}, \mathrm{fi}$ & Cs & No \\
\hline \multicolumn{5}{|c|}{ No or few hematopoietic cells } \\
\hline VAR2 & $\begin{array}{l}\text { Malaria-encoded } \\
\text { VAR2CSA }\end{array}$ & $\mathrm{pl}$ & cs & [69-73] \\
\hline
\end{tabular}

When using these different markers, different populations of tumor cells are captured [76]. In order to capture these populations at the same time, a combining of different markers could be used. In an attempt to use additional markers to increase the amount of CTCs captured, Beck et al. replaced part of the EpCAM particles in a CellSearch run with Her-2-, EGFR- and MUC-1-coated particles [88]. This change, however, decreased the capture efficiency. Wu et al. [89] compared EpCAM-based enrichment with a combination of EpCAM and MUC-1 in a similar fashion and also saw a decrease compared using to only EpCAM-coated particles. It seems the amount of EpCAM particles needs to remain sufficient for the capture of cells that are only or mostly EpCAM positive. One could increase the total amount of MNPs in order to keep the efficiency of the EpCAM capture; this will, however, also cause an increase in the number of healthy cells captured, thereby lowering the specificity of the test. It might be that different antibodies should be bound to the same magnetic nanoparticle in order to use multiple markers in order to capture CTCs more effectively.

Another way could be to use indirect labeling through biotin-labelled antibodies, which, in turn, can be captured using streptavidin-coupled MNPs. In this way the total amount of ferrofluid does 
not need to be increased to be able to use multiple antibodies at the same time. The downside of this approach is that the unbound antibody needs to be washed away before capture of the bound antibody can effectively take place.

\subsection{Binding Antibodies to Magnetic Particles}

There are several ways that can be used to bind antibodies to the surface of MNPs. The most commonly used method is via the streptavidin-biotin interaction, in which streptavidin-immobilized MNPs are coated with biotinylated antibodies through the high affinity interaction between streptavidin and biotin. The streptavidin-biotin interaction is one of the strongest non-covalent interactions in nature $\left(\mathrm{K}_{\mathrm{d}} \sim 10^{-14} \mathrm{M}\right)$. Its strength is considered to be approximately $10^{3}$ to $10^{6}$ times higher than an antigen-antibody interaction and remains stable under different $\mathrm{pH}$ environments [90-92]. The affinity of free biotin for avidin is even higher, but in almost all cases, streptavidin is used. Streptavidin and avidin have similar structures, both having four binding sites for biotin, but due to avidin being glycosylated it has a high isoelectric point $(\mathrm{pI}=10)$, causing non-specific binding to become a problem when using it. As streptavidin is not glycosylated, it has a low isoelectric point (pI = 5-6) $[93,94]$, and is widely used due to its lower non-specific binding.

Covalently binding streptavidin to the surface of MNPs through amino-carboxyl condensation is the most commonly used method, and antibodies can be indirectly attached to the MNPs through this method [37,95]. Li et al. [96] also successfully attached streptavidin to the surface of amino nanoparticles using glutaraldehyde as a linker. Similar to the principle of binding streptavidin on the surface of nanoparticles, it is possible to covalently bind antibodies directly to the surface of MNPs by condensing the amino carboxyl groups through EDC (1-Ethyl-3-(3-dimethylaminopropyl)carbodiimide)-NHS (N-hydroxysuccinimide) chemistry [37,95]. Li et al. [96] also successfully attached streptavidin to the surface of amino nanoparticles using glutaraldehyde as a linker. Similar to the principle of binding streptavidin on the surface of nanoparticles, it is possible to covalently bind antibodies directly to the surface of MNPs by condensing the amino carboxyl groups through EDC (1-Ethyl-3-(3-dimethylaminopropyl)carbodiimide)-NHS (N-hydroxysuccinimide) chemistry [38,40]. As the application of magnetic beads in scientific research has become common, magnetic beads bound with streptavidin or antibodies have been commercialized and can be easily bought.

\section{Characterization of Magnetic Particle Performance}

\section{Low Non-Specific Binding and No Agglomeration}

When separating a cell type with a high frequency from blood, it is in most cases not very problematic if a small percentage of the cells in the collected fraction are of a different cell type. If, however, the frequency of the population of interest declines, the presence of these unwanted cells becomes more problematic as their relative percentage in the resulting sample increases.

As an example, the EpCAM enrichment of the CellSearch system aimed at the enumeration of CTC has a 3.3-log depletion, but the average number of contaminating leukocytes in the resulting sample is still around 25,000 [97]. In contrast, the number of tumor cells is usually less than 10 [29]. Immunofluorescent labeling is used to discriminate the tumor cells from the leukocytes, but still some false positives are found in healthy individuals [29]. Andree et al. visualized the probability distributions of the staining intensity occurring on target and non-target cell populations, see figure 7 [98]. When the ratio of their numbers is $1: 1,1: 1000,1: 10,000$ and $1: 1,000,000$, respectively, $4.6 \%, 48.9 \%$, $70.3 \%$ and $95.2 \%$ of the stained cells could not be distinguished. One way to resolve this overlap is to introduce multiple parameters to distinguish tumor cells from healthy cells. As can be seen from Table 2, many targets are available; however, they are often only expressed on a subset of tumor cells and many will be needed to distinguish the majority of the CTCs. Even if a marker expressed on all tumor cells can be found, for an enriched DLA sample with a ratio of 1:1,000,000, it has been estimated that five different parameters will be needed to distinguish the majority of the target population [99]. 
For this reason, it is of the utmost importance that a magnetic particle, in order to be useful for the separation of rare cell populations, does not, or only very rarely, bind to cells in a non-specific manner.

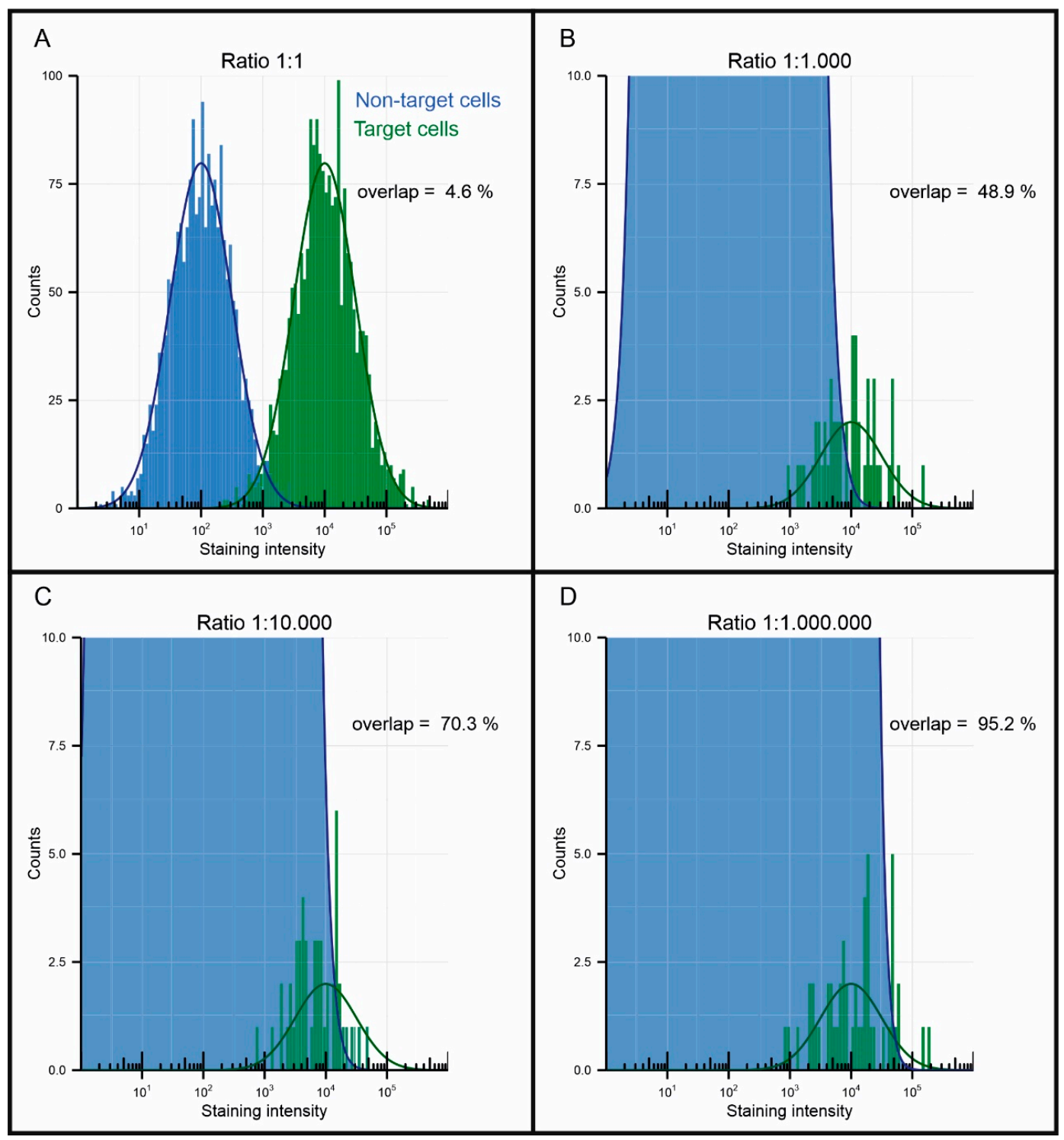

Figure 7. Visualization of the interference of non-target cells to the detection of target cells when using a target to non-target ratio of (A) 1:1, (B) 1:1,000, (C) 1:10,000 and (D) 1:1,000,000. Reprinted with permission from [98].

Non-specific capture of non-target cells can occur at different stages of the cell separation process. For example, cells binding to the nanoparticle surface, binding to a part of the antibody in a different manner (for example, Fc receptor binding) or cells getting trapped during separation. In some cases, it can also be that the target antigen is expressed in low amounts by a small fraction of the non-target cells, for instance the expression of MUC-1 in T-cells, leading to an increase in false positives [100].

Non-specific binding to the surface of nanoparticles is generally thought to be caused by physical absorption caused by electrostatic forces or hydrophobic interactions [101]. Furthermore, bare MNPs will agglomerate due to high surface energy and cause non-specific binding of other blood components due to the coordination reaction between the iron ions and the carboxyl groups in the protein, so the surface needs to be made up of molecules that do not show this type of interaction.

For this purpose, the particle surface is often coated to prevent the aggregation of the bare MNPs. Commonly used coatings are PEG [49], polyacrylic acid (PAA) [46,102], polyvinylpyrrolidone 
(PVP) [103], polydopamine (PDA) [104], dextran [105] and BSA [106,107]. The electrostatic repulsion or steric hindrance between these coated surfaces can prevent the agglomeration of nanoparticles, while at the same time non-specific binding is reduced due to the exposure of bare nanoparticles being avoided. Similarly, short-chain molecules such as PEG are also used as blocking agents to reduce non-specific adsorption. A clear overview of the different methods used for the surface modification of MNPs can be found in the review of Zhu et al. [108]. Besides the particle surface, other factors, such as the salt concentration and $\mathrm{pH}$ value of the solution, as well as the presence of a surfactant, can also affect non-specific binding.

There are also attempts to reduce the non-specific trapping of non-target cells during the separation process by designing unique structures. As these methods are not directly related to the magnetic nanoparticles used we will not go into details here [109].

\section{Separation of Magnetic Particles in Systems for CTC Enumeration}

Magnetic enrichment of cells was commercially introduced by Miltenyi in 1989 [33]. Today, the most used system for CTCs is still the CellSearch system, the only method cleared by the FDA for clinical CTC enumeration. The system enriches CTCs from $7.5 \mathrm{~mL}$ blood samples using EpCAM-functionalized ferrofluids for enrichment and fluorescent markers for labeling of the enriched sample. To date, clinical data involving more than 4700 patients has confirmed the value of CellSearch for predicting prognosis. The large size and high cost of the device limit the popularity of CellSearch system. Other commercial systems exist for the separation of magnetically bound CTCs, such as the Miltenyi autoMACS and MultiMACS, the Invitrogen KingFisher systems as well as magnetic separators for manual enrichment, such as BDs IMag, Invitrogens Dynamag or StemCells Easysep. Other methods have been developed, such as the MagSweeper, currently licensed to Illumina, in which a magnetic rod is moved through the solution in order to capture the magnetically labelled cells [110]. Most research into magnetic separation, however, is aimed at small, low-cost devices, and we will shortly describe these efforts here.

In order to capture the CTCs, MNP microfluidic chips are in these cases most often used in combination with external magnets [111]. In these chips, the capture efficiency is largely dependent on the magnetic array used. By using a micromagnet array that combines long-range permanent magnets and short-range thin-film micromagnets, it is possible to enhance the capture and control the distribution of the magnetic field up to the micrometer scale $[39,112,113]$. In order to capture the CTCs, MNP microfluidic chips are in these cases most often also used in microfluidic devices in combination with external magnets to capture the CTCs [111]. In these chips, the capture efficiency is largely depend on the magnetic array used. By using a micromagnet array device that combines long-range permanent magnets and short-range thin-film micromagnets, it is possible to enhance the capture by controlling and control the distribution of the magnetic field up to the micrometer scale $[39,112,113]$.

When the surface of the microchannel is flat, the liquid will flow through in a laminar flow pattern. If the binding of MNPs to cells needs to take place within the chip, this laminar flow pattern causes insufficient contact between the MNPs and target cells. For this reason, Stroock et al. designed microstructures on the inner surface to produce lateral flow and effectively mix solutions [114]. Herringbone structured chips have also been designed in order to create turbulence and facilitate the capture of CTC on the chips surface [115-117]. In order to maintain the captured CTC trapped in the chip while still allowing easy recovery, dead-end side chambers can be used [109]. The combination of this approach with an increasing magnetic gradient facilitates the classification of CTC by their level of antigen expression [118]. The designed microstructures on the inner wall surface produce lateral flow in order to effectively mix solutions [114]. Herringbone structured chips have also been designed in order to create turbulence and facilitate the capture of CTCs on the chip's surface [115-117]. In order to maintain the captured CTCs trapped in the chip while also still allowing easy recovery, dead-end side chambers can be used [109]. The combination of this approach with an increasing magnetic gradient facilitates the classification of the CTCs by their level of antigen expression [118]. 
By using a porous membrane impermeable to cells as a capture surface, the unbound particles can be separated from the captured cells while the possible volume flow might also increases [119]. When using a larger pore size but making the filter surface itself magnetic, the distance of the cells to the magnetic surface can be decreased to facilitate capture [120].

Instead of magnetically trapping the cells in the chip, it is also possible to divert them to a different outlet port to facilitate separation [121-123]. This can be done using a positive separation with superparamagnetic particles, but also a negative depletion using diamagnetic particles is possible $[124,125]$

Not only chip-based approaches have been used for the magnetic enrichment of CTCs; other methods have also been developed using magnetic rods wrapped in plastic [126] or using MNPs with positively charged surfaces [127].

As shown, DLA can be used to increase the sampling volume, but some researchers have also focused on capturing CTCs in vivo, directly from the patients' blood, by using immunomagnetic enrichment. This can be done via an extracorporeal chip. Here, the blood is extracted from the patient, meaning labeling and separation takes place outside of the patient [128]. Another option involves a magnetic wire that can be placed intravascularly to separate the injected MNPs and CTCs directly from the blood stream [129].

These different efforts to extract CTCs are almost all reported with a proven level of recovery using one or more cell lines, sometimes even patient samples. When comparing these technologies on their benefit, it is, however, important to not only focus on the possible recovery, but also the usability of the resulting sample for downstream single cell isolation and analysis. In many cases, a low sample purity, the inability to extract all of the captured cells or the used fixation will impede the success of the downstream single-cell isolation technologies, as well as the (epi-)genetic, protein or functionality assay. There are many different single-cell isolation and analysis technologies available, which have different sample requirements. An overview of the existing single-cell isolation technologies can be found in the review of Valihrach [130], while other reviews focus on the different types of analysis possible after isolation [131-133].

\section{Conclusions}

For the enrichment of CTCs using MNPs, the characteristics of the particles are of great importance. We have discussed the different characteristics of MNPs and their impact on the enrichment of CTCs. We emphasized the importance of the high-purity enrichment for CTC identification and isolation, especially for large sample volumes. Common synthesis and surface modification methods as well as different strategies for the use of immunomagnetic particles are discussed with a focus on improving specificity. Panels of multicolor antibodies that recognize specific targets with low non-specificity increases the reliability of CTC detection, hence we have listed the available antigens for the readers' reference. The characteristics of the different magnetic configurations were compared and finally we briefly introduced some of the existing applications of immunomagnetic particles for tumor cell enrichment.

In practice, insufficient depletion caused by the non-specific binding of MNPs to white blood cells hinders the identification of CTCs and the reduction of these cells can greatly facilitate their identification. In recent years, great progress has been made in the synthesis of MNPs in the field of materials chemistry and it would be very beneficial if this progress could be implemented into cell separation applications. In addition, although people often use blocking reagents to reduce non-specific binding, the extent and cause are rarely reported. Due to the rarity of CTCs, larger sample volumes will need to be processed, potentially in vivo, making the specificity of the binding even more important.

Author Contributions: Writing-original draft preparation, P.L., M.S.; writing-review and editing, M.S., L.W.M.M.T. and P.J. All authors have read and agreed to the published version of the manuscript.

Funding: The first author was funded by the China Scholarship Council (CSC) from the Ministry of Education of China. 
Conflicts of Interest: The authors declare no conflict of interest. The funders had no role in the design of the study; in the collection, analyses, or interpretation of data; in the writing of the manuscript, or in the decision to publish the results.

\section{References}

1. Dean, R.S.; Davis, C.W. Magnetic Separation of Ores; US Government Printing Office: Washington, DC, USA, 1941.

2. Melville, D.; Paul, F.; Roath, S. Direct magnetic separation of red cells from whole blood. Nature 1975, 255, 706-706. [CrossRef] [PubMed]

3. Molday, R.S.; Yen, S.P.S.; Rembaum, A. Application of magnetic microspheres in labelling and separation of cells. Nature 1977, 268, 437-438. [CrossRef]

4. Coumans, F.; Terstappen, L. Detection and Characterization of Circulating Tumor Cells by the CellSearch Approach. In Whole Genome Amplification: Methods and Protocols; Kroneis, T., Ed.; Springer: New York, NY, USA, 2015; pp. 263-278.

5. Masud, M.K.; Na, J.; Younus, M.; Hossain, M.S.A.; Bando, Y.; Shiddiky, M.J.A.; Yamauchi, Y. Superparamagnetic nanoarchitectures for disease-specific biomarker detection. Chem. Soc. Rev. 2019, 48, 5717-5751. [CrossRef] [PubMed]

6. Majidi, S.; Zeinali Sehrig, F.; Farkhani, S.M.; Soleymani Goloujeh, M.; Akbarzadeh, A. Current methods for synthesis of magnetic nanoparticles. Artif. Cells Nanomed. Biotechnol. 2016, 44, 722-734. [CrossRef] [PubMed]

7. Colombo, M.; Carregal-Romero, S.; Casula, M.F.; Gutiérrez, L.; Morales, M.P.; Böhm, I.B.; Heverhagen, J.T.; Prosperi, D.; Parak, W.J. Biological applications of magnetic nanoparticles. Chem. Soc. Rev. 2012, 41, 4306-4334. [CrossRef] [PubMed]

8. Laurent, S.; Forge, D.; Port, M.; Roch, A.; Robic, C.; Vander Elst, L.; Muller, R.N. Magnetic Iron Oxide Nanoparticles: Synthesis, Stabilization, Vectorization, Physicochemical Characterizations, and Biological Applications. Chem. Rev. 2008, 108, 2064-2110. [CrossRef]

9. Hasany, S.; Ahmed, I.; Rajan, J.; Rehman, A. Systematic review of the preparation techniques of iron oxide magnetic nanoparticles. Nanosci. Nanotechnol. 2012, 2, 148-158. [CrossRef]

10. van Dalum, G.; Stam, G.J.; Scholten, L.F.; Mastboom, W.J.; Vermes, I.; Tibbe, A.G.; De Groot, M.R.; Terstappen, L.W. Importance of circulating tumor cells in newly diagnosed colorectal cancer. Int. J. Oncol. 2015, 46, 1361-1368. [CrossRef]

11. Janni, W.J.; Rack, B.; Terstappen, L.W.; Pierga, J.Y.; Taran, F.A.; Fehm, T.; Hall, C.; de Groot, M.R.; Bidard, F.C.; Friedl, T.W.; et al. Pooled Analysis of the Prognostic Relevance of Circulating Tumor Cells in Primary Breast Cancer. Clin. Cancer Res. 2016, 22, 2583-2593. [CrossRef]

12. Tibbe, A.G.; Miller, M.C.; Terstappen, L.W. Statistical considerations for enumeration of circulating tumor cells. Cytometry 2007, 71, 154-162. [CrossRef]

13. Rao, C.; Bui, T.; Connelly, M.; Doyle, G.; Karydis, I.; Middleton, M.R.; Clack, G.; Malone, M.; Coumans, F.A.; Terstappen, L.W. Circulating melanoma cells and survival in metastatic melanoma. Int. J. Oncol. 2011, 38, 755-760. [PubMed]

14. Coumans, F.A.W.; Doggen, C.J.M.; Attard, G.; de Bono, J.S.; Terstappen, L.W.M.M. All circulating EpCAM+CK+CD45- objects predict overall survival in castration-resistant prostate cancer. Ann. Oncol. 2010, 21, 1851-1857. [CrossRef] [PubMed]

15. Eifler, R.L.; Lind, J.; Falkenhagen, D.; Weber, V.; Fischer, M.B.; Zeillinger, R. Enrichment of circulating tumor cells from a large blood volume using leukapheresis and elutriation: Proof of concept. Cytom. B Clin. Cytom. 2011, 80, 100-111. [CrossRef] [PubMed]

16. Fischer, J.C.; Niederacher, D.; Topp, S.A.; Honisch, E.; Schumacher, S.; Schmitz, N.; Zacarias Fohrding, L.; Vay, C.; Hoffmann, I.; Kasprowicz, N.S.; et al. Diagnostic leukapheresis enables reliable detection of circulating tumor cells of nonmetastatic cancer patients. Proc. Natl. Acad. Sci. USA 2013, 110, 16580-16585. [CrossRef] [PubMed]

17. Coumans, F.A.W.; Siesling, S.; Terstappen, L.W.M.M. Detection of cancer before distant metastasis. BMC Cancer 2013, 13, 283. [CrossRef] [PubMed] 
18. Keeney, M.; Gratama, J.W.; Chin-Yee, I.H.; Sutherland, D.R. Isotype controls in the analysis of lymphocytes and CD34+ stem and progenitor cells by flow cytometry-time to let go? Cytometry 1998, 34, $280-283$. [CrossRef]

19. Chen, P.; Huang, Y.-Y.; Hoshino, K.; Zhang, X. Multiscale immunomagnetic enrichment of circulating tumor cells: From tubes to microchips. Lab A Chip 2014, 14, 446-458. [CrossRef]

20. Hoshino, K.; Chen, P.; Huang, Y.-Y.; Zhang, X. Computational Analysis of Microfluidic Immunomagnetic Rare Cell Separation from a Particulate Blood Flow. Anal. Chem. 2012, 84, 4292-4299. [CrossRef]

21. Lu, P.J.; Weitz, D.A. Colloidal Particles: Crystals, Glasses, and Gels. Annu. Rev. Condens. Matter Phys. 2013, 4, 217-233.

22. Wang, H.; Zhao, X.; Han, X.; Tang, Z.; Song, F.; Zhang, S.; Zhu, Y.; Guo, W.; He, Z.; Guo, Q.; et al. Colloidal stability of $\mathrm{Fe}_{3} \mathrm{O}_{4}$ magnetic nanoparticles differentially impacted by dissolved organic matter and cations in synthetic and naturally-occurred environmental waters. Environ. Pollut. 2018, 241, 912-921. [CrossRef]

23. Kang, J.H.; Um, E.; Diaz, A.; Driscoll, H.; Rodas, M.J.; Domansky, K.; Watters, A.L.; Super, M.; Stone, H.A.; Ingber, D.E. Optimization of Pathogen Capture in Flowing Fluids with Magnetic Nanoparticles. Small 2015, 11, 5657-5666. [CrossRef] [PubMed]

24. Wu, L.; Mendoza-Garcia, A.; Li, Q.; Sun, S. Organic Phase Syntheses of Magnetic Nanoparticles and Their Applications. Chem. Rev. 2016, 116, 10473-10512. [CrossRef] [PubMed]

25. Li, Q.; Kartikowati, C.W.; Horie, S.; Ogi, T.; Iwaki, T.; Okuyama, K. Correlation between particle size/domain structure and magnetic properties of highly crystalline $\mathrm{Fe}_{3} \mathrm{O}_{4}$ nanoparticles. Sci. Rep. 2017, 7, 9894. [CrossRef] [PubMed]

26. Kim, B.H.; Lee, N.; Kim, H.; An, K.; Park, Y.I.; Choi, Y.; Shin, K.; Lee, Y.; Kwon, S.G.; Na, H.B.; et al. Large-Scale Synthesis of Uniform and Extremely Small-Sized Iron Oxide Nanoparticles for High-Resolution T1 Magnetic Resonance Imaging Contrast Agents. J. Am. Chem. Soc. 2011, 133, 12624-12631. [CrossRef] [PubMed]

27. Daou, T.J.; Grenèche, J.M.; Pourroy, G.; Buathong, S.; Derory, A.; Ulhaq-Bouillet, C.; Donnio, B.; Guillon, D.; Begin-Colin, S. Coupling Agent Effect on Magnetic Properties of Functionalized Magnetite-Based Nanoparticles. Chem. Mater. 2008, 20, 5869-5875. [CrossRef]

28. McCloskey, K.E.; Chalmers, J.J.; Zborowski, M. Magnetic Cell Separation: Characterization of Magnetophoretic Mobility. Anal. Chem. 2003, 75, 6868-6874. [CrossRef]

29. Allard, W.J.; Matera, J.; Miller, M.C.; Repollet, M.; Connelly, M.C.; Rao, C.; Tibbe, A.G.J.; Uhr, J.W.; Terstappen, L.W.M.M. Tumor Cells Circulate in the Peripheral Blood of All Major Carcinomas but not in Healthy Subjects or Patients With Nonmalignant Diseases. Clin. Cancer Res. 2004, 10, 6897. [CrossRef]

30. Osman, O.; Toru, S.; Dumas-Bouchiat, F.; Dempsey, N.M.; Haddour, N.; Zanini, L.F.; Buret, F.; Reyne, G.; Frenea-Robin, M. Microfluidic immunomagnetic cell separation using integrated permanent micromagnets. Biomicrofluidics 2013, 7, 54115. [CrossRef]

31. Sun, C.; Hassanisaber, H.; Yu, R.; Ma, S.; Verbridge, S.S.; Lu, C. Paramagnetic Structures within a Microfluidic Channel for Enhanced Immunomagnetic Isolation and Surface Patterning of Cells. Sci. Rep. 2016, 6, 29407. [CrossRef]

32. Huang, Y.-Y.; Chen, P.; Wu, C.-H.; Hoshino, K.; Sokolov, K.; Lane, N.; Liu, H.; Huebschman, M.; Frenkel, E.; Zhang, J.X.J. Screening and Molecular Analysis of Single Circulating Tumor Cells Using Micromagnet Array. Sci. Rep. 2015, 5, 16047. [CrossRef]

33. Miltenyi, S.; Müller, W.; Weichel, W.; Radbruch, A. High gradient magnetic cell separation with MACS. Cytometry 1990, 11, 231-238. [CrossRef] [PubMed]

34. Molday, R.S. Magnetic iron-Dextran Microspheres. U.S. Patent 4,452,773, 5 June 1984.

35. Gijs, M.A.M. Magnetic bead handling on-chip: New opportunities for analytical applications. Microfluid. Nanofluidics 2004, 1, 22-40. [CrossRef]

36. Hildonen, S.; Skarpen, E.; Halvorsen, T.G.; Reubsaet, L. Isolation and mass spectrometry analysis of urinary extraexosomal proteins. Sci. Rep. 2016, 6, 36331. [CrossRef] [PubMed]

37. Unni, M.; Zhang, J.; George, T.J.; Segal, M.S.; Fan, Z.H.; Rinaldi, C. Engineering magnetic nanoparticles and their integration with microfluidics for cell isolation. J. Colloid Interface Sci. 2020, 564, 204-215. [CrossRef]

38. Xu, H.; Aguilar, Z.P.; Yang, L.; Kuang, M.; Duan, H.; Xiong, Y.; Wei, H.; Wang, A. Antibody conjugated magnetic iron oxide nanoparticles for cancer cell separation in fresh whole blood. Biomaterials 2011, 32, 9758-9765. [CrossRef] 
39. Zhang, F.; Wu, L.; Nie, W.; Huang, L.; Zhang, J.; Li, F.; Xie, H.-Y. Biomimetic Microfluidic System for Fast and Specific Detection of Circulating Tumor Cells. Anal. Chem. 2019, 91, 15726-15731. [CrossRef]

40. Kim, J.; Tran, V.T.; Oh, S.; Kim, C.-S.; Hong, J.C.; Kim, S.; Joo, Y.-S.; Mun, S.; Kim, M.-H.; Jung, J.-W.; et al. Scalable Solvothermal Synthesis of Superparamagnetic $\mathrm{Fe}_{3} \mathrm{O}_{4}$ Nanoclusters for Bioseparation and Theragnostic Probes. ACS Appl. Mater. Interfaces 2018, 10, 41935-41946. [CrossRef]

41. Vidal-Vidal, J.; Rivas, J.; Lopez-Quintela, M.A. Synthesis of monodisperse maghemite nanoparticles by the microemulsion method. Colloids Surf. A Physicochem. Eng. Asp. 2006, 288, 44-51. [CrossRef]

42. Massart, R. Preparation of aqueous magnetic liquids in alkaline and acidic media. IEEE Trans. Magn. 1981, 17, 1247-1248. [CrossRef]

43. Molday, R.S.; Mackenzie, D. Immunospecific ferromagnetic iron-dextran reagents for the labeling and magnetic separation of cells. J. Immunol. Methods 1982, 52, 353-367. [CrossRef]

44. Ugelstad, J.; Hansen, F.K. Kinetics and Mechanism of Emulsion Polymerization. Rubber Chem. Technol. 1976, 49, 536-609. [CrossRef]

45. Charles, S.; Owen, J.S.S.; D'Angelo, L.; Liberti, P.A. Magnetic Polymer Particles. U.S. Patent 4,795,698, 3 January 1989.

46. Feng, Y.; White, A.; Hein, J.; Appel, E.; Fordyce, P. MRBLES 2.0: High-throughput generation of chemically functionalized spectrally and magnetically-encoded hydrogel beads using a simple single-layer microfluidic device. bioRxiv 2020. [CrossRef]

47. Park, J.; An, K.; Hwang, Y.; Park, J.-G.; Noh, H.-J.; Kim, J.-Y.; Park, J.-H.; Hwang, N.-M.; Hyeon, T. Ultra-large-scale syntheses of monodisperse nanocrystals. Nat. Mater. 2004, 3, 891-895. [CrossRef]

48. Yu, W.W.; Falkner, J.C.; Yavuz, C.T.; Colvin, V.L. Synthesis of monodisperse iron oxide nanocrystals by thermal decomposition of iron carboxylate salts. Chem. Commun. 2004, 20, 2306-2307. [CrossRef] [PubMed]

49. Ge, Q.; Su, J.; Chung, T.-S.; Amy, G. Hydrophilic Superparamagnetic Nanoparticles: Synthesis, Characterization, and Performance in Forward Osmosis Processes. Ind. Eng. Chem. Res. 2011, 50, 382-388. [CrossRef]

50. Nielsen, M.A.; Resende, M.; de Jongh, W.A.; Ditlev, S.B.; Mordmüller, B.; Houard, S.; Ndam, N.T.; Agerbæk, M.Ø.; Hamborg, M.; Massougbodji, A.; et al. The Influence of Sub-Unit Composition and Expression System on the Functional Antibody Response in the Development of a VAR2CSA Based Plasmodium falciparum Placental Malaria Vaccine. PLoS ONE 2015, 10, e0135406. [CrossRef]

51. Hassan, E.M.; Willmore, W.G.; DeRosa, M.C. Aptamers: Promising Tools for the Detection of Circulating Tumor Cells. Nucleic Acid Ther. 2016, 26, 335-347. [CrossRef]

52. Rao, C.G.; Chianese, D.; Doyle, G.V.; Miller, M.C.; Russell, T.; Sanders, R.A.; Terstappen, L.W. Expression of epithelial cell adhesion molecule in carcinoma cells present in blood and primary and metastatic tumors. Int. J. Oncol. 2005, 27, 49-57. [CrossRef]

53. Went, P.T.; Lugli A Fau-Meier, S.; Meier S Fau-Bundi, M.; Bundi M Fau-Mirlacher, M.; Mirlacher M Fau-Sauter, G.; Sauter G Fau-Dirnhofer, S.; Dirnhofer, S. Frequent EpCam protein expression in human carcinomas. Hum. Pathol. 2004, 35, 122-128. [CrossRef]

54. Cristofanilli, M.; Hayes, D.F.; Budd, G.T.; Ellis, M.J.; Stopeck, A.; Reuben, J.M.; Doyle, G.V.; Matera, J.; Allard, W.J.; Miller, M.C.; et al. Circulating tumor cells: A novel prognostic factor for newly diagnosed metastatic breast cancer. J. Clin. Oncol. 2005, 23, 1420-1430. [CrossRef]

55. de Bono, J.S.; Scher, H.I.; Montgomery, R.B.; Parker, C.; Miller, M.C.; Tissing, H.; Doyle, G.V.; Terstappen, L.W.; Pienta, K.J.; Raghavan, D. Circulating tumor cells predict survival benefit from treatment in metastatic castration-resistant prostate cancer. Clin. Cancer Res. 2008, 14, 6302-6309. [CrossRef] [PubMed]

56. Hayes, D.F.; Cristofanilli, M.; Budd, G.T.; Ellis, M.J.; Stopeck, A.; Miller, M.C.; Matera, J.; Allard, W.J.; Doyle, G.V.; Terstappen, L.W. Circulating tumor cells at each follow-up time point during therapy of metastatic breast cancer patients predict progression-free and overall survival. Clin. Cancer Res. 2006, 12, 4218-4224. [CrossRef] [PubMed]

57. Alix-Panabières, C.; Pantel, K. Challenges in circulating tumour cell research. Nat. Rev. Cancer 2014, 14, 623. [CrossRef] [PubMed]

58. Galletti, G.; Sung, M.S.; Vahdat, L.T.; Shah, M.A.; Santana, S.M.; Altavilla, G.; Kirby, B.J.; Giannakakou, P. Isolation of breast cancer and gastric cancer circulating tumor cells by use of an anti HER2-based microfluidic device. Lab Chip 2014, 14, 147-156. [CrossRef] 
59. Lee, H.J.; Cho, H.Y.; Oh, J.H.; Namkoong, K.; Lee, J.G.; Park, J.M.; Lee, S.S.; Huh, N.; Choi, J.W. Simultaneous capture and in situ analysis of circulating tumor cells using multiple hybrid nanoparticles. Biosens. Bioelectron. 2013, 47, 508-514. [CrossRef]

60. Que, Z.; Luo, B.; Zhou, Z.; Dong, C.; Jiang, Y.; Wang, L.; Shi, Q.; Tian, J. Establishment and characterization of a patient-derived circulating lung tumor cell line in vitro and in vivo. Cancer Cell Int. 2019, 19, 21. [CrossRef]

61. Thege, F.I.; Gruber, C.N.; Cardle, I.I.; Cong, S.H.; Lannin, T.B.; Kirby, B.J. anti-EGFR capture mitigates EMTand chemoresistance-associated heterogeneity in a resistance-profiling CTC platform. Anal. Biochem. 2019, 577, 26-33. [CrossRef]

62. Ohnaga, T.; Takei, Y.; Nagata, T.; Shimada, Y. Highly efficient capture of cancer cells expressing EGFR by microfluidic methods based on antigen-antibody association. Sci. Rep. 2018, 8, 12005. [CrossRef]

63. Onstenk, W.; Kraan, J.; Mostert, B.; Timmermans, M.M.; Charehbili, A.; Smit, V.T.; Kroep, J.R.; Nortier, J.W.; van de Ven, S.; Heijns, J.B.; et al. Improved Circulating Tumor Cell Detection by a Combined EpCAM and MCAM CellSearch Enrichment Approach in Patients with Breast Cancer Undergoing Neoadjuvant Chemotherapy. Mol. Cancer 2015, 14, 821-827. [CrossRef]

64. Bande, M.F.; Santiago, M.; Muinelo-Romay, L.; Blanco, M.J.; Mera, P.; Capeans, C.; Pardo, M.; Piñeiro, A. Detection of circulating melanoma cells in choroidal melanocytic lesions. BMC Res. Notes 2015, 8, 452. [CrossRef]

65. Li, N.; Zong, S.; Zhang, Y.; Wang, Z.; Wang, Y.; Zhu, K.; Yang, K.; Wang, Z.; Chen, B.; Cui, Y. A SERS-colorimetric dual-mode aptasensor for the detection of cancer biomarker MUC1. Anal. Bioanal. Chem. 2020, 412, 5707-5718. [CrossRef] [PubMed]

66. Thege, F.I.; Lannin, T.B.; Saha, T.N.; Tsai, S.; Kochman, M.L.; Hollingsworth, M.A.; Rhim, A.D.; Kirby, B.J. Microfluidic immunocapture of circulating pancreatic cells using parallel EpCAM and MUC1 capture: Characterization, optimization and downstream analysis. Lab Chip 2014, 14, 1775-1784. [CrossRef] [PubMed]

67. Wang, W.; Liu, S.; Li, C.; Wang, Y.; Yan, C. Dual-target recognition sandwich assay based on core-shell magnetic mesoporous silica nanoparticles for sensitive detection of breast cancer cells. Talanta 2018, 182, 306-313. [CrossRef] [PubMed]

68. Yin, X.; Chen, B.; He, M.; Hu, B. A Multifunctional Platform for the Capture, Release, And Enumeration of Circulating Tumor Cells Based on Aptamer Binding, Nicking Endonuclease-Assisted Amplification, And Inductively Coupled Plasma Mass Spectrometry Detection. Anal. Chem. 2020, 92, 10308-10315. [CrossRef]

69. Salanti, A.; Clausen, T.M.; Agerbæk, M.Ø.; AlNakouzi, N.; Dahlbäck, M.; Oo, H.Z.; Lee, S.; Gustavsson, T.; Rich, J.R.; Hedberg, B.J.; et al. Targeting Human Cancer by a Glycosaminoglycan Binding Malaria Protein. Cancer Cell 2015, 28, 500-514. [CrossRef]

70. Agerbæk, M.Ø.; Bang-Christensen, S.; Salanti, A. Fighting Cancer Using an Oncofetal Glycosaminoglycan-Binding Protein from Malaria Parasites. Trends Parasitol. 2019, 35, 178-181. [CrossRef]

71. Agerbæk, M.Ø.; Bang-Christensen, S.R.; Yang, M.-H.; Clausen, T.M.; Pereira, M.A.; Sharma, S.; Ditlev, S.B.; Nielsen, M.A.; Choudhary, S.; Gustavsson, T.; et al. The VAR2CSA malaria protein efficiently retrieves circulating tumor cells in an EpCAM-independent manner. Nat. Commun. 2018, 9, 3279. [CrossRef]

72. Bang-Christensen, S.R.; Pedersen, R.S.; Pereira, M.A.; Clausen, T.M.; Løppke, C.; Sand, N.T.; Ahrens, T.D.; Jørgensen, A.M.; Lim, Y.C.; Goksøyr, L. Capture and Detection of Circulating Glioma Cells Using the Recombinant VAR2CSA Malaria Protein. Cells 2019, 8, 998. [CrossRef]

73. Sand, N.T.; Petersen, T.B.; Bang-Christensen, S.R.; Ahrens, T.D.; Loppke, C.; Jorgensen, A.M.; Gustavsson, T.; Choudhary, S.; Theander, T.G.; Salanti, A.; et al. Optimization of rVAR2-Based Isolation of Cancer Cells in Blood for Building a Robust Assay for Clinical Detection of Circulating Tumor Cells. Int. J. Mol. Sci. 2020, 21, 2401. [CrossRef] [PubMed]

74. Andree, K.C.; Mentink, A.; Nguyen, A.T.; Goldsteen, P.; van Dalum, G.; Broekmaat, J.J.; van Rijn, C.J.M.; Terstappen, L.W.M.M. Tumor cell capture from blood by flowing across antibody-coated surfaces. Lab A Chip 2019, 19, 1006-1012. [CrossRef] [PubMed] 
75. Martin, V.M.; Siewert C Fau-Scharl, A.; Scharl A Fau-Harms, T.; Harms T Fau-Heinze, R.; Heinze R Fau-Ohl, S.; Ohl S Fau-Radbruch, A.; Radbruch A Fau-Miltenyi, S.; Miltenyi S Fau-Schmitz, J.; Schmitz, J. Immunomagnetic enrichment of disseminated epithelial tumor cells from peripheral blood by MACS. Exp. Hematol. 1998, 26, 252-264. [PubMed]

76. Schneck, H.; Gierke, B.; Uppenkamp, F.; Behrens, B.; Niederacher, D.; Stoecklein, N.H.; Templin, M.F.; Pawlak, M.; Fehm, T.; Neubauer, H.; et al. EpCAM-Independent Enrichment of Circulating Tumor Cells in Metastatic Breast Cancer. PLoS ONE 2015, 10, e0144535. [CrossRef] [PubMed]

77. Neves, M.; Azevedo, R.; Lima, L.; Oliveira, M.I.; Peixoto, A.; Ferreira, D.; Soares, J.; Fernandes, E.; Gaiteiro, C.; Palmeira, C.; et al. Exploring sialyl-Tn expression in microfluidic-isolated circulating tumour cells: A novel biomarker and an analytical tool for precision oncology applications. New Biotechnol. 2019, 49, 77-87. [CrossRef] [PubMed]

78. Liu, H.; Wang, Z.; Chen, C.; Ding, P.; Sun, N.; Pei, R. Dual-antibody Modified PLGA Nanofibers for Specific Capture of Epithelial and Mesenchymal CTCs. Colloids Surf. 2019, 181, 143-148. [CrossRef]

79. Wang, Z.; Sun, N.; Liu, H.; Chen, C.; Ding, P.; Yue, X.; Zou, H.; Xing, C.; Pei, R. High-Efficiency Isolation and Rapid Identification of Heterogeneous Circulating Tumor Cells (CTCs) Using Dual-Antibody-Modified Fluorescent-Magnetic Nanoparticles. ACS Appl. Mater. Interfaces 2019, 11, 39586-39593. [CrossRef]

80. Po, J.W.; Roohullah, A.; Lynch, D.; DeFazio, A.; Harrison, M.; Harnett, P.R.; Kennedy, C.; de Souza, P.; Becker, T.M. Improved ovarian cancer EMT-CTC isolation by immunomagnetic targeting of epithelial EpCAM and mesenchymal N-cadherin. J. Circ. Biomark 2018, 7, 1849454418782617. [CrossRef]

81. Esmaeilsabzali, H.; Payer, R.T.M.; Guo, Y.; Cox, M.E.; Parameswaran, A.M.; Beischlag, T.V.; Park, E.J. Development of a microfluidic platform for size-based hydrodynamic enrichment and PSMA-targeted immunomagnetic isolation of circulating tumour cells in prostate cancer. Biomicrofluidics 2019, 13, 014110. [CrossRef]

82. Yin, C.; Wang, Y.; Ji, J.; Cai, B.; Chen, H.; Yang, Z.; Wang, K.; Luo, C.; Zhang, W.; Yuan, C.; et al. Molecular Profiling of Pooled Circulating Tumor Cells from Prostate Cancer Patients Using a Dual-Antibody-Functionalized Microfluidic Device. Anal. Chem. 2018, 90, 3744-3751. [CrossRef]

83. KOLOSTOVA, K.; PINTEROVA, D.; HOFFMAN, R.M.; BOBEK, V. Circulating Human Prostate Cancer Cells from an Orthotopic Mouse Model Rapidly Captured by Immunomagnetic Beads and Imaged by GFP Expression. Anticancer Res. 2011, 31, 1535-1539.

84. Hughes, A.D.; Mattison, J.; Powderly, J.D.; Greene, B.T.; King, M.R. Rapid isolation of viable circulating tumor cells from patient blood samples. J. Vis. Exp. 2012, 64, e4248. [CrossRef]

85. Mitchell, M.J.; Castellanos, C.A.; King, M.R. Immobilized surfactant-nanotube complexes support selectin-mediated capture of viable circulating tumor cells in the absence of capture antibodies. J. Biomed. Mater. Res. A 2015, 103, 3407-3418. [CrossRef] [PubMed]

86. Launiere, C.; Gaskill, M.; Czaplewski, G.; Myung, J.H.; Hong, S.; Eddington, D.T. Channel surface patterning of alternating biomimetic protein combinations for enhanced microfluidic tumor cell isolation. Anal. Chem. 2012, 84, 4022-4028. [CrossRef] [PubMed]

87. Myung, J.H.; Launiere, C.A.; Eddington, D.T.; Hong, S. Enhanced tumor cell isolation by a biomimetic combination of E-selectin and anti-EpCAM: Implications for the effective separation of circulating tumor cells (CTCs). Langmuir 2010, 26, 8589-8596. [CrossRef] [PubMed]

88. Beck, T.N.; Boumber, Y.A.; Aggarwal, C.; Pei, J.; Thrash-Bingham, C.; Fittipaldi, P.; Vlasenkova, R.; Rao, C.; Borghaei, H.; Cristofanilli, M.; et al. Circulating tumor cell and cell-free RNA capture and expression analysis identify platelet-associated genes in metastatic lung cancer. BMC Cancer 2019, 19, 603. [CrossRef]

89. Wu, J.; Raba, K.; Guglielmi, R.; Behrens, B.; Van Dalum, G.; Flügen, G.; Koch, A.; Patel, S.; Knoefel, W.T.; Stoecklein, N.H.; et al. Magnetic-Based Enrichment of Rare Cells from High Concentrated Blood Samples. Cancers 2020, 12, 933. [CrossRef]

90. Jain, A.; Cheng, K. The principles and applications of avidin-based nanoparticles in drug delivery and diagnosis. J. Control. Release 2017, 245, 27-40. [CrossRef]

91. Diamandis, E.P.; Christopoulos, T.K. The biotin-(strept)avidin system: Principles and applications in biotechnology. Clin. Chem. 1991, 37, 625-636. [CrossRef]

92. Weber, P.C.; Ohlendorf, D.H.; Wendoloski, J.J.; Salemme, F.R. Structural origins of high-affinity biotin binding to streptavidin. Science 1989, 243, 85. [CrossRef] 
93. Kuzuya, A.; Numajiri, K.; Kimura, M.; Komiyama, M. Single-Molecule Accommodation of Streptavidin in Nanometer-Scale Wells Formed in DNA Nanostructures. Nucleic Acids Symp. Ser. 2008, 52, 681-682. [CrossRef]

94. Avvakumova, S.; Colombo, M.; Galbiati, E.; Mazzucchelli, S.; Rotem, R.; Prosperi, D. Chapter 6-Bioengineered Approaches for Site Orientation of Peptide-Based Ligands of Nanomaterials. In Biomedical Applications of Functionalized Nanomaterials; Sarmento, B., das Neves, J., Eds.; Elsevier: Amsterdan, The Netherlands, 2018; pp. 139-169. [CrossRef]

95. Gao, X.; Cui, Y.; Levenson, R.M.; Chung, L.W.K.; Nie, S. In vivo cancer targeting and imaging with semiconductor quantum dots. Nat. Biotechnol. 2004, 22, 969-976. [CrossRef]

96. Li, S.; Liu, H.; He, N. Covalent Binding of Streptavidin on Gold Magnetic Nanoparticles for Bead Array Fabrication. J. Nanosci. Nanotechnol. 2010, 10, 4875-4882. [CrossRef] [PubMed]

97. Andree, K.C.; Mentink, A.; Zeune, L.L.; Terstappen, L.W.M.M.; Stoecklein, N.H.; Neves, R.P.; Driemel, C.; Lampignano, R.; Yang, L.; Neubauer, H.; et al. Toward a real liquid biopsy in metastatic breast and prostate cancer: Diagnostic LeukApheresis increases CTC yields in a European prospective multicenter study (CTCTrap). Int. J. Cancer 2018, 143, 2584-2591. [CrossRef] [PubMed]

98. Andree, K.C.; van Dalum, G.; Terstappen, L.W.M.M. Challenges in circulating tumor cell detection by the CellSearch system. Mol. Oncol. 2016, 10, 395-407. [CrossRef] [PubMed]

99. Stoecklein, N.H.; Fischer, J.C.; Niederacher, D.; Terstappen, L.W. Challenges for CTC-based liquid biopsies: Low CTC frequency and diagnostic leukapheresis as a potential solution. Expert Rev. Mol. Diagn. 2016, 16, 147-164. [CrossRef]

100. Correa, I.; Plunkett, T.; Vlad, A.; Mungul, A.; Candelora-Kettel, J.; Burchell, J.M.; Taylor-papadimitriou, J.; Finn, O.J. Form and pattern of MUC1 expression on T cells activated in vivo or in vitro suggests a function in T-cell migration. Immunology 2003, 108, 32-41. [CrossRef]

101. Yu, D.; Tang, L.; Dong, Z.; Loftis, K.A.; Ding, Z.; Cheng, J.; Qin, B.; Yan, J.; Li, W. Effective reduction of non-specific binding of blood cells in a microfluidic chip for isolation of rare cancer cells. Biomater. Sci. 2018, 6, 2871-2880. [CrossRef]

102. Sanchez, L.M.; Martin, D.A.; Alvarez, V.A.; Gonzalez, J.S. Polyacrylic acid-coated iron oxide magnetic nanoparticles: The polymer molecular weight influence. Colloids Surf. A 2018, 543, 28-37. [CrossRef]

103. Rose, P.A.; Praseetha, P.K.; Bhagat, M.; Alexander, P.; Abdeen, S.; Chavali, M. Drug embedded PVP coated magnetic nanoparticles for targeted killing of breast cancer cells. Technol. Cancer Res. Treat. 2013, 12, 463-472. [CrossRef]

104. Ma, Y.R.; Zhang, X.L.; Zeng, T.; Cao, D.; Zhou, Z.; Li, W.H.; Niu, H.; Cai, Y.Q. Polydopamine-coated magnetic nanoparticles for enrichment and direct detection of small molecule pollutants coupled with MALDI-TOF-MS. ACS Appl. Mater. Interfaces 2013, 5, 1024-1030. [CrossRef]

105. Hong, R.Y.; Feng, B.; Chen, L.L.; Liu, G.H.; Li, H.Z.; Zheng, Y.; Wei, D.G. Synthesis, characterization and MRI application of dextran-coated Fe3O4 magnetic nanoparticles. Biochem. Eng. J. 2008, 42, 290-300. [CrossRef]

106. Zhang, B.; Wang, X.; Liu, F.; Cheng, Y.; Shi, D. Effective Reduction of Nonspecific Binding by Surface Engineering of Quantum Dots with Bovine Serum Albumin for Cell-Targeted Imaging. Langmuir 2012, 28, 16605-16613. [CrossRef] [PubMed]

107. Wang, Q.; Zhang, M.; Wang, L.; Gu, Y. Effective reduction of non-specific binding by bovine serum albumin modified quantum dot surface for cell targeted imaging. In Twelfth International Conference on Photonics and Imaging in Biology and Medicine (PIBM 2014); SPIE Press: Bellingham, WA, USA, 2014.

108. Zhu, N.; Ji, H.; Yu, P.; Niu, J.; Farooq, M.U.; Akram, M.W.; Udego, I.O.; Li, H.; Niu, X. Surface Modification of Magnetic Iron Oxide Nanoparticles. Nanomaterials 2018, 8, 810. [CrossRef] [PubMed]

109. Kang, J.H.; Krause, S.; Tobin, H.; Mammoto, A.; Kanapathipillai, M.; Ingber, D.E. A combined micromagnetic-microfluidic device for rapid capture and culture of rare circulating tumor cells. Lab A Chip 2012, 12, 2175-2181. [CrossRef] [PubMed]

110. Cann, G.M.; Gulzar, Z.G.; Cooper, S.; Li, R.; Luo, S.; Tat, M.; Stuart, S.; Schroth, G.; Srinivas, S.; Ronaghi, M.; et al. mRNA-Seq of single prostate cancer circulating tumor cells reveals recapitulation of gene expression and pathways found in prostate cancer. PLoS ONE 2012, 7, e49144. [CrossRef]

111. Hoshino, K.; Huang, Y.-Y.; Lane, N.; Huebschman, M.; Uhr, J.W.; Frenkel, E.P.; Zhang, X. Microchip-based immunomagnetic detection of circulating tumor cells. Lab A Chip 2011, 11, 3449-3457. [CrossRef] 
112. Chen, P.; Huang, Y.-Y.; Hoshino, K.; Zhang, J.X.J. Microscale Magnetic Field Modulation for Enhanced Capture and Distribution of Rare Circulating Tumor Cells. Sci. Rep. 2015, 5, 8745. [CrossRef]

113. Yu, X.; Feng, X.; Hu, J.; Zhang, Z.-L.; Pang, D.-W. Controlling the Magnetic Field Distribution on the Micrometer Scale and Generation of Magnetic Bead Patterns for Microfluidic Applications. Langmuir 2011, 27, 5147-5156. [CrossRef]

114. Stroock, A.D.; Dertinger, S.K.W.; Ajdari, A.; Mezić, I.; Stone, H.A.; Whitesides, G.M. Chaotic Mixer for Microchannels. Science 2002, 295, 647. [CrossRef]

115. Stott, S.L.; Hsu, C.-H.; Tsukrov, D.I.; Yu, M.; Miyamoto, D.T.; Waltman, B.A.; Rothenberg, S.M.; Shah, A.M.; Smas, M.E.; Korir, G.K.; et al. Isolation of circulating tumor cells using a microvortex-generating herringbone-chip. Proc. Natl. Acad. Sci. USA 2010, 107, 18392. [CrossRef]

116. Shi, W.; Wang, S.; Maarouf, A.; Uhl, C.G.; He, R.; Yunus, D.; Liu, Y. Magnetic particles assisted capture and release of rare circulating tumor cells using wavy-herringbone structured microfluidic devices. Lab A Chip 2017, 17, 3291-3299. [CrossRef]

117. Zhang, L.; Xu, Z.; Kang, Y.; Xue, P. Three-dimensional microfluidic chip with twin-layer herringbone structure for high efficient tumor cell capture and release via antibody-conjugated magnetic microbeads. Electrophoresis 2018, 39, 1452-1459. [CrossRef] [PubMed]

118. Kwak, B.; Lee, J.; Lee, D.; Lee, K.; Kwon, O.; Kang, S.; Kim, Y. Selective isolation of magnetic nanoparticle-mediated heterogeneity subpopulation of circulating tumor cells using magnetic gradient based microfluidic system. Biosens. Bioelectron. 2017, 88, 153-158. [CrossRef] [PubMed]

119. Chang, C.-L.; Huang, W.; Jalal, S.I.; Chan, B.-D.; Mahmood, A.; Shahda, S.; O'Neil, B.H.; Matei, D.E.; Savran, C.A. Circulating tumor cell detection using a parallel flow micro-aperture chip system. Lab A Chip 2015, 15, 1677-1688. [CrossRef] [PubMed]

120. Earhart, C.M.; Hughes, C.E.; Gaster, R.S.; Ooi, C.C.; Wilson, R.J.; Zhou, L.Y.; Humke, E.W.; Xu, L.; Wong, D.J.; Willingham, S.B.; et al. Isolation and mutational analysis of circulating tumor cells from lung cancer patients with magnetic sifters and biochips. Lab A Chip 2014, 14, 78-88. [CrossRef]

121. Kim, S.; Han, S.-I.; Park, M.-J.; Jeon, C.-W.; Joo, Y.-D.; Choi, I.-H.; Han, K.-H. Circulating Tumor Cell Microseparator Based on Lateral Magnetophoresis and Immunomagnetic Nanobeads. Anal. Chem. 2013, 85, 2779-2786. [CrossRef]

122. Cho, H.; Kim, J.; Han, S.-I.; Han, K.-H. Analytical evaluation for somatic mutation detection in circulating tumor cells isolated using a lateral magnetophoretic microseparator. Biomed. Microdevices 2016, 18, 91. [CrossRef]

123. Park, J.W.; Lee, N.-R.; Cho, S.M.; Jung, M.Y.; Ihm, C.; Lee, D.-S. Microdevice for Separation of Circulating Tumor Cells Using Embedded Magnetophoresis with V-shaped Ni-Co Nanowires and Immuno-nanomagnetic Beads. ETRI J. 2015, 37, 233-240. [CrossRef]

124. Ozkumur, E.; Shah, A.M.; Ciciliano, J.C.; Emmink, B.L.; Miyamoto, D.T.; Brachtel, E.; Yu, M.; Chen, P.I.; Morgan, B.; Trautwein, J.; et al. Inertial focusing for tumor antigen-dependent and -independent sorting of rare circulating tumor cells. Sci. Transl. Med. 2013, 5, 179ra147. [CrossRef]

125. Mishra, A.; Dubash, T.D.; Edd, J.F.; Jewett, M.K.; Garre, S.G.; Karabacak, N.A.-O.; Rabe, D.A.-O.; Mutlu, B.A.-O.; Walsh, J.A.-O.; Kapur, R.; et al. Ultrahigh-throughput magnetic sorting of large blood volumes for epitope-agnostic isolation of circulating tumor cells. Proc. Natl. Acad. Sci. USA 2020, 117, 16839-16847. [CrossRef]

126. Powell, A.A.; Talasaz, A.H.; Zhang, H.; Coram, M.A.; Reddy, A.; Deng, G.; Telli, M.L.; Advani, R.H.; Carlson, R.W.; Mollick, J.A.; et al. Single Cell Profiling of Circulating Tumor Cells: Transcriptional Heterogeneity and Diversity from Breast Cancer Cell Lines. PLoS ONE 2012, 7, e33788. [CrossRef]

127. Wu, S.; Gu, L.; Qin, J.; Zhang, L.; Sun, F.; Liu, Z.; Wang, Y.; Shi, D. Rapid Label-Free Isolation of Circulating Tumor Cells from Patients' Peripheral Blood Using Electrically Charged Fe3O4 Nanoparticles. ACS Appl. Mater. Interfaces 2020, 12, 4193-4203. [CrossRef] [PubMed]

128. Tang, M.; Xia, H.-F.; Xu, C.-M.; Feng, J.; Ren, J.-G.; Miao, F.; Wu, M.; Wu, L.-L.; Pang, D.-W.; Chen, G.; et al. Magnetic chip based extracorporeal circulation: A new tool for circulating tumor cell in vivo detection. Anal. Chem. 2019, 91, 15260-15266. [CrossRef] [PubMed]

129. Vermesh, O.; Aalipour, A.; Ge, T.J.; Saenz, Y.; Guo, Y.; Alam, I.S.; Park, S.-m.; Adelson, C.N.; Mitsutake, Y.; Vilches-Moure, J.; et al. An intravascular magnetic wire for the high-throughput retrieval of circulating tumour cells in vivo. Nat. Biomed. Eng. 2018, 2, 696-705. [CrossRef] [PubMed] 
130. Valihrach, L.; Androvic, P.; Kubista, M. Platforms for Single-Cell Collection and Analysis. Int. J. Mol. Sci. 2018, 19, 807. [CrossRef] [PubMed]

131. Song, Y.; Xu, X.; Wang, W.; Tian, T.; Zhu, Z.; Yang, C. Single cell transcriptomics: Moving towards multi-omics. Analyst 2019, 144, 3172-3189. [CrossRef]

132. Baslan, T.; Hicks, J. Unravelling biology and shifting paradigms in cancer with single-cell sequencing. Nat. Rev. Cancer 2017, 17, 557-569. [CrossRef]

133. Paolillo, C.; Londin, E.; Fortina, P. Single-Cell Genomics. Clin. Chem. 2019, 65, 972-985. [CrossRef]

Publisher's Note: MDPI stays neutral with regard to jurisdictional claims in published maps and institutional affiliations.

(C) 2020 by the authors. Licensee MDPI, Basel, Switzerland. This article is an open access article distributed under the terms and conditions of the Creative Commons Attribution (CC BY) license (http://creativecommons.org/licenses/by/4.0/). 